\title{
BUILDING INCLUSIVE MARKETS IN RURAL BANGLADESH: HOW INTERMEDIARIES WORK INSTITUTIONAL VOIDS
}

\author{
JOHANNA MAIR \\ Stanford University \\ IGNASI MARTÍ \\ EM LYON Business School \\ MARC J. VENTRESCA \\ University of Oxford
}

\begin{abstract}
Much effort goes into building markets as a tool for economic and social development; those pursuing or promoting market building, however, often overlook that in too many places social exclusion and poverty prevent many, especially women, from participating in and accessing markets. Building on data from rural Bangladesh and analyzing the work of a prominent intermediary organization, we uncover institutional voids as the source of market exclusion and identify two sets of activities-redefining market architecture and legitimating new actors-as critical for building inclusive markets. We expose voids as analytical spaces and illustrate how they result from conflict and contradiction among institutional bits and pieces from local political, community, and religious spheres. Our findings put forward a perspective on market building that highlights the on-the-ground dynamics and attends to the institutions at play, to their consequences, and to a more diverse set of inhabitants of institutions.
\end{abstract}

If someone who has no property rights under the law, who has had no formal education, who has no legal right to divorce, who will very likely be beaten if she seeks employment outside the home, says that she endorses traditions of modesty, purity, and selfabnegation, it is not clear that we should consider this the last word on the matter.

-Marta Nussbaum

This article is the outcome of a truly collaborative effort, and all three authors contributed equally. Although our work is about breaking conventions, we for once adhere to conventions in publishing and list authors in alphabetical order. We would like to thank Tima Bansal for her exceptional guidance and three anonymous reviewers who encouraged and helped us to find and refine the empirical and theoretical nuggets in this project. This article would not have been possible without BRAC and the people that make BRAC. We particularly thank Fazle Abed for sharing insights and wisdom. We are also grateful for the following people who graciously shared their concerns and suggestions: Yasser Bhatti, Dana Brown, David Courpasson, Gregoire Croidieu, Frédéric Delmar, Catherine Dolan, Ingrid Erickson, Fabrizio Ferraro, Royston Greenwood, Carol Leonard, Ray Loveridge, John Meyer, Philippe Monin, Mari Sako, Saras Sarasvathy, Marc Schneiberg, Dick Scott, and Christian Seelos. This work also greatly benefited from discussions at the 2006 Summer Institute "Trajectories of Capitalism" at the Center of Advanced Studies in the Behavioral Sciences, an economic sociology panel at the 2006 Annual Meetings of the American Sociological Association, the 7th Neo Institutionalism Workshop at EM LYON Business School, and the 2011 Strategy and Innovation conference at the Said Business School.
Researchers and policy makers have long argued that markets are engines for economic growth and that market-based activities constitute an importan tool for social progress, economic empowerment: and human development (Seelos \& Mair, 2007; Stiglitz, 1989; UNDP, 2008). In this spirit, many contemporary policy initiatives make poor women's market access and participation central to their experiments and pilot programs-an aspect of policy broadly referred to as "developing inclusive markets" (Mendoza \& Thelen, 2008). Yet these wellintended interventions often overlook the role that local institutions such as customs, religious credos, and social norms play in compromising the potential for women's economic activity. One of our fieldwork informants in Bangladesh said, "How can I go to the market? I am a woman!" Her words exemplify how women in too many places are excluded from marketbased activities and expose how social conventions prevent them from market access. The simple quote also points to the limits of promoting the role of markets without analyzing how local context and institutional arrangements shape markets and market-based activity (Banerjee \& Duflo, 2011).

Institutions, metaphorically referred to as the "rules of the game" (North, 1990), matter for markets; they enable and support market activity (Campbell \& Lindberg, 1990; De Soto, 2000; Greif, 2006; Sen, 1999). Where such institutions are absent or weak, management and strategy scholars point to the pres- 
ence of "institutional voids," realities that can impact market formation, economic growth, and development (Khanna \& Palepu, 1997; Webb, Tihanyi, Ireland, \& Sirmon, 2009). Researchers further note that absent and weak market institutions reinforce existing social inequalities as market access and opportunity are governed by local institutional arrangements (Crow, 2001; Rodrik, 2007). Such local arrangements consist of complex interlocks of formal institutions, such as constitutions, laws, property rights, and governmental regulations, and informal institutions, such as customs, traditions, and religious beliefs (Fligstein, 2001; North, 1991), that not only enable but also constrain market activity. They determine the rules of the game and, importantly, who is allowed to play.

Local realities are the point of departure for this study. Our objective is to clarify market-building processes by interrogating the concept of institutional voids in institutionally complex contextsparticularly where markets and market-based activities are seen as tools for economic development. Drawing on an in-depth qualitative study, we focus our empirical efforts on the case of Bangladesh and the work of BRAC, ${ }^{1}$ a prominent, pervasive local intermediary agency. Whereas many studies view institutional voids as "empty" of specific institutions, our findings suggest that voids occur amidst institutional plurality and are the intermediate outcome of conflict and contradiction among local political, community, and religious spheres. This fresh perspective detects institutional voids as an important driver of market exclusion and provides an analytical anchor for the study of market-building processes. Our analysis of the varied work of BRAC over several decades suggests that market access and participation are negotiable and market boundaries are potentially permeable for actors who have been excluded.

The perspective on market building we put forward highlights "on-the-ground" dynamics and attends to the consequences of market building for the people involved. Our findings complement and extend research on the institutional formation and infrastructure of markets by highlighting market building as inhabited - that is, as replete with people and activity, albeit focused to varied purposes.

\footnotetext{
${ }^{1}$ BRAC originally stood for "Bangladesh Rehabilitation Assistance Committee," in line with its focus on relief work after natural disasters. In 1973, BRAC was renamed "Bangladesh Rural Advancement Committee" to reflect its focus on development. Almost three decades later, when BRAC was already working in the country's urban slums and had started to work internationally, it became "Building Resources Across Communities."
}

More specifically, we explain how markets can become inclusive places: legitimated arenas for interdependent social and economic activity where formal possibilities align with practical access across gender, race, religion, and social class.

\section{MARKET BUILDING AND INSTITUTIONAL VOIDS}

\section{Markets, Institutions, and Context}

Institutionalists throughout the social sciences agree that markets are systems of economic exchange and spaces for social interaction as well as complex bundles of institutions (Geertz, 1978; La Porta, Lopez-de-Silanes, Shleifer, \& Vishny, 1998; McMillan, 2002; North, 1990). A context-specific and often complex assembly of institutions including both formal rules and informal norms generates market microstructures and assembly of institutions that configure sociopolitical contexts and organize the "terms of action" (Fligstein, 2001). These institutional architectures vary across polities, comprising rules for what issues are public and collective and which actors are authorized to engage these issues (Jepperson \& Meyer, 1991). Along with recognizing such cross-polity variation, scholars warn of the "need to maintain a healthy scepticism toward the idea that a specific type of institution is the only type that is compatible with a well-functioning market economy" (Rodrik, 2007: 162-163). This contention signals the need for inquiries about market-building processes in institutionally complex contexts (Granovetter \& McGuire, 1998; Mair \& Martí, 2009; Santos \& Eisenhardt, 2009; Spicer, McDermott, \& Kogut, 2000).

Building markets is neither easy nor unproblematic. Regardless of how efficient a particular institutional arrangement has proven itself in a specific context, the efficacy and impact of that same institutional assembly will likely vary in a different context. Institutional frameworks of meaning and authority shape the conditions of market building and the particular tactics that actors use (Biggart \& Guillen, 1999; Hamilton \& Biggart, 1988). Recent work in the economic sociology of markets (Fligstein, 2001; Zelizer, 2005), the varieties of capitalism (Hall \& Soskice, 2001), and institutional economics (Greif, 2006; North, 1990; Rodrik, 2007) points to the varied intertwining of culture and politics in the social organization of markets and economies. Despite observing differences in foci and mechanisms, scholars argue that markets are constructed rather than "natural" or spontaneous entities. This scholarship also challenges the dominant, simplified (and simplifying) view of markets 
as cleanly distinguished from the infrastructure of their local contexts. Careful attention to the rules of the game in markets points to the relevance of the context and processes by which they emerge (Fligstein, 2001; Greif, 2006; North, 1990; Rodrik, 2007). The process of institutionalizing the rules that govern exchange and market-based activity is ongoing and observable, and as such it provides a lens for observing market building and the activities of diverse institutional actors (Santos \& Eisenhardt, 2009; Spicer et al., 2000; Stark, 1996).

\section{Institutional Voids}

Recent work on institutional voids in strategy and economics recognizes the central role that institutions-and their absence-play in developing market economies and in shaping the behavior of a particular set of actors: firms and entrepreneurs. Standard claims locate the source of key market institutions such as property rights and autonomy in state action and rules (Campbell \& Lindberg, 1990; La Porta et al., 1998; North, 1990). Where properly designed and implemented, these institutions provide the rules of the game that support formation of ideal typical markets to form. If these institutions are absent or weak, the argument goes, institutional voids occur, and a compensatory social structure is needed to spur market formation and operation (Greif, 2006; Khanna \& Palepu, 1997). Building on new institutional economics and agency theory, Khanna and Palepu (1997, 2000) extended Leff's (1976) work on business groups in developing economies, to contend that large business groups imitate and substitute for missing institutions to ensure market function in the event of market failures due to the presence of institutional voids (Khanna, Palepu, \& Sinha, 2005; Khanna \& Rivkin, 2006). In this stream of research, institutional voids are typically presented as inhibitors of the establishment of Western-style markets. The proposed solutions typically favor the transfer of institutional technology as a compensatory mechanism over local experimentation and recombination.

Following Khanna and colleagues, and drawing from a broader spectrum of research on institutions (North, 1990; Powell \& DiMaggio, 1991), recent scholarship in organizational theory and strategy has focused on the consequences of institutional voids on business strategy. Meyer, Estrin, Bhaumik, and Peng (2009) showed that the relative strength or weakness of various institutional frameworks impacts alternative modes of entry in India, Vietnam, South Africa, and Egypt. Puffer, McCarthy, and Boisot (2009) revealed that weak and lacking formal institutions in Russia and China force entrepreneurs to rely on trust within networks as well as on blat and guanxi, respectively (see also Ahlstrom \& Bruton, 2006). Additionally, Chakrabarty (2009) showed that institutional voids influence family ownership patterns in 27 countries.

A second set of studies points to the impact that institutional voids have on entrepreneurial processes in "base of the pyramid" (BOP) markets and local informal economies. Webb et al. (2009) suggested several ways that institutional incongruence and weak enforcement of formal institutions facilitate entrepreneurial processes in an informal economy. Cross-sector alliances between commercial companies and local social entrepreneurs have been shown to remove the "hurdles of implementing BOP models" (Seelos \& Mair, 2007: 49) by reducing the uncertainty caused by weak market institutions (Webb, Kistruck, Ireland, \& Ketchen, 2010). Together, these studies reinforce the importance of understanding the institutional infrastructure of markets and foreground the impact of institutional voids on effective market functioning (North, 1990; Peng, Sun, Pinkham, \& Chen, 2009). They also showcase a productive conversation between institutional economists and strategy researchers, one that highlights a shared interpretation of institutional voids as spaces empty of institutions. This interpretation stands in contrast to the interpretation favored by sociologists and anthropologists, who emphasize the abundance and complexity of institutions present in similar contexts and situations and who focus on the people participating (and not participating) in markets (Banfield, 1958; Friedland \& Alford, 1991; Geertz, 1978; Zelizer, 2010). Engaging the economic and strategy line of research with the sociological and anthropological line of research opens up a salient debate on the processes involved in building markets as inclusive arenas for social interaction and economic exchange. Although previous studies have elaborated on a varied set of consequences resulting from the presence of institutional voids, much is still unknown about how institutional voids are constituted, how they relate to existing institutional arrangements, and how they matter for local populations.

\section{Market Building in and around Institutional Voids}

Institutional economists and their colleagues in finance have developed substantial empirical and theoretical arguments about the institutional infrastructures and rules that support market formation and associated economic development (La Porta et al., 1998; Morrison, 2004; Morrison \& White, 2009; North, 1990). This diverse work finds substantial policy expression in the legacy of North and in the work of neo-Hirschman scholars (Chan, 2002; Rodrik, 2007). The gist of the argument is that specific 
configurations of (micro and macro) institutions conduce to market formation. In the absence of these institutional arrangements (i.e., in the presence of institutional voids), there is much difficulty in establishing markets and the necessary outcomes such as transparency and efficiency. Much of the policy translation of this work, however, reinforces the imagery that markets come into being in equilibrium. Moreover, although the attention to the "putting in place" of markets and market reforms is important, it neglects the complex work and lessons for policy from attending to the early stages and dynamics of market building.

For this focus on early moments, we have recourse to economic and cultural sociologists whose work is reinserting activity into market formation. At the broader societal level, work on markets as politics views the institutional architecture of markets as the outcome of social movement-like struggles between incumbents and challengers (Bourdieu, 2005; Fligstein, 2001), highlighting the struggles among actors to harness the cultural, political and institutional resources to organize markets and economies (Anteby, 2010; Biggart \& Guillen, 1999; Hamilton \& Biggart, 1988). This research makes explicit the link between social movements, corporations, the state apparatus, and markets (Lounsbury, Ventresca, \& Hirsch, 2003; Schneiberg, 2007; Tilly \& Tilly, 1998). Such emerging imagery of market building draws on an understanding of institutions as both obdurate and stable but also not without activity and contest.

A parallel stream of scholarship from the social sciences prompts yet another useful reading on the role of institutions and institutional dynamics in the process of market building. An important line of work by sociologists shows that markets are often built with, rather than on, the bit and pieces of institutions (Stark, 1996). These insights reposition attention onto the plurality of incumbent institutional arrangements that support economies and markets (Hamilton \& Biggart, 1988; Ostrom, 1990; Thelen, 2004). This scholarship also shows how, in many cases, these incumbent institutional arrangements supplant institutions that support Khanna et al.'s model of the market economy or "market capitalism." Moreover, whereas many studies on institutional voids have, to a large extent, omitted people (for an exception see Webb, Tihanyi, Ireland, \& Sirmon [2009]) and neglected the disenfranchised, an emerging body of literature is beginning to focus on the reality of activity present in "inhabited institutions" (Hallett \& Ventresca, 2006: 231). This nascent trajectory in the field is (re)infusing institutionalism with a "lost" microsociology (Barley,
2008; Hallett, 2010; Kellogg, 2009), in turn enriching the context of economic sociology.

We draw on this understanding of institutional configurations and dynamics to investigate the sources of institutional voids. We treat voids as analytical spaces at the interface of several institutional spheres, each with its own animating logic of meanings and social practices (Friedland \& Alford, 1991). This reading departs from the conventional view that privileges modern/Western interpretations of key market institutions and emphasizes the functioning of ideal markets. By accentuating the situated and intermediate nature of institutional voids, we develop a view of voids that originates in the presence of plural, often contending, institutional arrangements (Banfield, 1958; Fourcade, 2007; Friedland \& Alford, 1991; Kogut et al., 2000; Sako, 2009; Stark, 1996), rather than continuing the view of "empty" institutional space. The analytic point to be made here is that even the ideal typical market promised by standard market institutions can reflect broader inequalities in a society and thus result in exclusionary markets. Our approach links institutional voids to grounded sources for limits on market participation and access. This approach also generates conceptual and empirical claims about how institutional plurality, conflict, and contradiction contribute to theorizing on inclusive markets and toward their potential implementation. We also see this as an opportunity to integrate scholarship focused on market consequences with the standard work on markets and institutional voids. Studies of market consequences vary in focus, but are especially well developed in terms of policy issues such as the distributional impacts of markets (Easterly, 2002; Stiglitz, 2000), cultural effects on endogenous preferences (Bowles, 1998), questions of social empowerment and the exclusion from labor markets (Banerjee \& Duflo, 2011), and the emerging work on inclusive markets (Mendoza \& Thelen, 2008).

To summarize, we extend the research on institutions and markets to put forward a perspective on market building that highlights the on-the-ground dynamics in complex institutional contexts. To advance this perspective, we pose two broad questions to guide our empirical analysis of building inclusive markets in rural Bangladesh: (1) How do institutional voids arise in institutionally complex settings, with what consequences for market access and participation? (2) What organizational and other activities work these voids to build inclusive markets? To answer the first question, we focus on two standard market institutions, property rights and autonomy, engaging this standard view with work on plural institutional spheres. Drawing on this analysis, we ex- 
plore the second question with a detailed case study of a prominent local intermediary agency in Bangladesh and its portfolio of initiatives and activities to address market inclusion.

\section{RESEARCH DESIGN, DATA, AND METHODS}

\section{Research Setting}

To probe the concept of institutional voids and to examine market building processes in an institutionally complex context, we focus on the case of BRAC (Mair \& Marti, 2009; Sachs, 2005; Smillie, 2009). Bangladesh is a complex country setting in which to analyze institutional voids and market building. Despite substantial progress in poverty alleviation and an overall economic growth rate of 6 percent in recent years within the country, nearly half of the estimated 156 million inhabitants of Bangladesh live below the poverty line (World Bank, 2010). BRAC, considered to be the world's largest development organization in reach and staff scale (Economist, 2010; Smillie, $2009),{ }^{2}$ is present in all 64 districts of Bangladesh, operating in about 70,000 villages-a reach that affects the life of 80 percent of the entire population (BRAC, 2009).

Prevailing institutional configurations in Bangladesh act to limit poor, rural inhabitants-particularly women-from accessing and participating in markets. These arrangements have a disproportionate impact on access, despite formal constitutional and political guarantees for the equal status of all Bangladeshi citizens in all areas of public life (Crow, 2001; Pereira, 2002). Market access and participation are further complicated by the amalgam of secular and religious dimensions that define public and economic life in Bangladesh (Kabeer, 2000). Such structural and institutional complexity also poses a serious impediment to sustaining economic and social development (Heritage Foundation, 2010).

Bangladesh's institutional arrangements make it a telling analytic case in which to explore the experimental and "extreme" nature of rural marketbuilding processes (Eisenhardt \& Graebner, 2007; Flyvbjerg, 2011; Pettigrew, 1990; Yin, 1994). Our high-relief observations also support a welcome agenda of formulating generalizable insights in this scholarly area. Finally, our case selection responds well to recent calls for "unconventional" organiza-

\footnotetext{
2 The original and primary work of BRAC is in Bangladesh. Since 2002 BRAC has also expanded operations into other countries in Asia (Afghanistan, Pakistan, and Sri Lanka), Africa (Liberia, Sierra Leone, Southern Sudan, Tanzania, and Uganda), and Latin America (Haiti) with experiments to diffuse its core models.
}

tional research conducted to develop new knowledge about organizational phenomena (Bamberger \& Pratt, 2010: 665): our emphasis on an organization-rich view of market-building processes directly links organizational theory and studies of market building representing other perspectives.

\section{The Organizational Case of BRAC}

Development researchers typically distinguish among a set of different development strategies and orientations among agencies (Korten, 1987). Korten identified three distinctive orientations: (a) relief and welfare, (b) local self-reliance, and (c) sustainable systems development. He further observed that there exists an "underlying direction of movement that makes it appropriate to label these orientations as first, second, and third generation" (Korten, 1987: 147). Although these generations of orientations simultaneously coexist within the larger community of nongovernmental organizations (NGOs), it is only in rare cases that they coexist in a single NGO (Korten, 1987). BRAC is one of those rare cases.

Fazle Hasan Abed founded BRAC in 1972 as a small-scale relief and rehabilitation project in Bangladesh after the War of Liberation in 1971 (Chen, 1983; Smillie, 2009). Over the years, BRAC has shifted in mission and focus from being a relief operation focused on strategic development and poverty alleviation to being a social mobilization organization rooted in a Marxist tradition, to, most recently, a poverty alleviation agent characterized by system building for and around markets for the least advantaged. Currently, BRAC reaches about 80 percent of the total number of villages in the country via its core organizing vehicle, the village organization (VO)-a decentralized model of local activity and intervention.

BRAC has experimented with an array of different activities and programs ranging from microfinance, health services, nonformal education, and human rights and legal aid support. In the 1990s, $\mathrm{BRAC}$ began to incorporate market mechanisms as a means of poverty alleviation into its primary approach (Lovell, 1992). In parallel, BRAC shifted from targeting village-level communities, as was customary in its 1970 s and 1980 s programs, to a near-exclusive focus today on women's economic empowerment and participation.

Over time, BRAC leadership has come to recognize that access to financial services is an important, but insufficient, means of involving poor and marginalized people in market-based activities (Mair \& Martí, 2009). This recognition led to the decision to set up social enterprises that facilitate entrepreneurial efforts and sustainable livelihoods 
in the late 1990s. These enterprises, which include livestock and fisheries (e.g., dairy, poultry), health (e.g., iodized salt), and agriculture (e.g., cold storage, sericulture), provide access to assets, support product marketing, and foster entrepreneurial and market activities that create local jobs.

BRAC and its contemporary portfolio of marketbased programs provide a useful analytic opportunity to examine market building in a complex institutional context in which market access and participation are impeded for many. Thus, we focus on BRAC's initiatives to build inclusive markets and leverage market-based activities as they simultaneously address the complex institutional context.

\section{Data}

The data we present come from multiple rounds of data collection and a variety of sources: participant observation, retrieval of archival documents, and in-depth interviews by two of the authors intermittently over six years, 2005-11. Between March 2005 and January 2006, two of the authors conducted 58 semistructured interviews, primarily at BRAC offices and in local villages in Bangladesh. The interviews increased in focus and depth over the period because of the iterative and cumulative nature of the fieldwork process.

We identified informants by sampling from various programs across multiple hierarchical levels in BRAC; we sampled within other organizations as well. The bulk of our interviews were conducted in English; interviews with Bangla-speaking informants (primarily participants in rural areas) were conducted with the assistance of a local interpreter. Each interview lasted between 20 minutes and three hours, followed a standard protocol for capturing emerging themes in field research (Spradley, 1979; Strauss \& Corbin, 1998), and was audio-recorded and later transcribed verbatim.

At the end of the first round of interviews, we decided to focus our data collection on a few BRAC programs in greater depth. We applied theoretical sampling (Denzin, 1989), a recommended approach for analytical induction (Bansal \& Roth, 2000), to identify these programs. We sought to capture a broad set of activities and practices as well as different periods in BRAC's strategic development within the sample. We used the cases to organize and stimulate data analysis, rather than as a means to expose variance.

In consultation with BRAC leadership, we selected four programs: Education; Social Development; Human Rights and Legal Education (HRLE); and Challenging the Frontiers of Poverty Reduction/Targeting the Ultra Poor (CFRP/TUP). Table 1 displays a detailed list of the different data sources utilized to investigate each of the four target programs. Each has a distinctive focus, target population, and inception date. They are also all ongoing into the current period. Additionally, each program took shape at a different point in the evolution of BRAC's strategies for poverty alleviation. Because of this, we treat each program as exemplary of a key challenge regarding market building (Rodrik, 2007). With these selected areas of investigation in place, we conducted 17 additional interviews between 2008 and 2010 with internal and external informants. We used our direct and repeated interview access to the BRAC founder and chairman, Fazle Abed, to identify program directors for interviews. Using these leads as a basis for snowball sampling (Lincoln \& Guba, 1985), we identified a second set of informants. Using a purposeful sampling strategy (Kumar, Stern, \& Anderson, 1993), we sought to uncover key insights or information about the origins, development, or activities of the four programs. Throughout the interview phase, we used a repeated comparison strategy to compare data across both programs and informants and identify substantive points of synergy or juxtaposition (Glaser \& Strauss, 1967).

As we completed the second set of interviews, we started to refine emerging themes and asked respondents to comment directly on specific aspects of these nascent findings. We used our conversations with the chairman and the four program directors to check our analysis. This use of external informants mitigated the potential biases of any individual respondent (Miller, Cardinal, \& Glick, 1997) and enabled us to induce richer insights from our aggregate data (Santos \& Eisenhardt, 2009). Appendix A summarizes the final roster of persons interviewed from BRAC $(n=56)$ and from other agencies and sectors $(n=19)$.

Interviews were supplemented with several periods of participant observation. Two of the authors observed a total of 17 meetings, which included both on-the-ground meetings within the different BRAC programs (e.g., popular theater performance, legal education classes) and also meetings at other organizations (e.g., microcredit meetings, garment factories). Meeting observation time totaled approximately 40 hours over the course of the fieldwork. During observations, we took field notes on site and wrote up detailed accounts after each visit. Field observation notes were not coded in detail but were used to illuminate the complex nature of the situation in which BRAC works, particularly key cultural and situational specificities that emerged from direct contact with the women in 
TABLE 1

Overview of Focal Programs

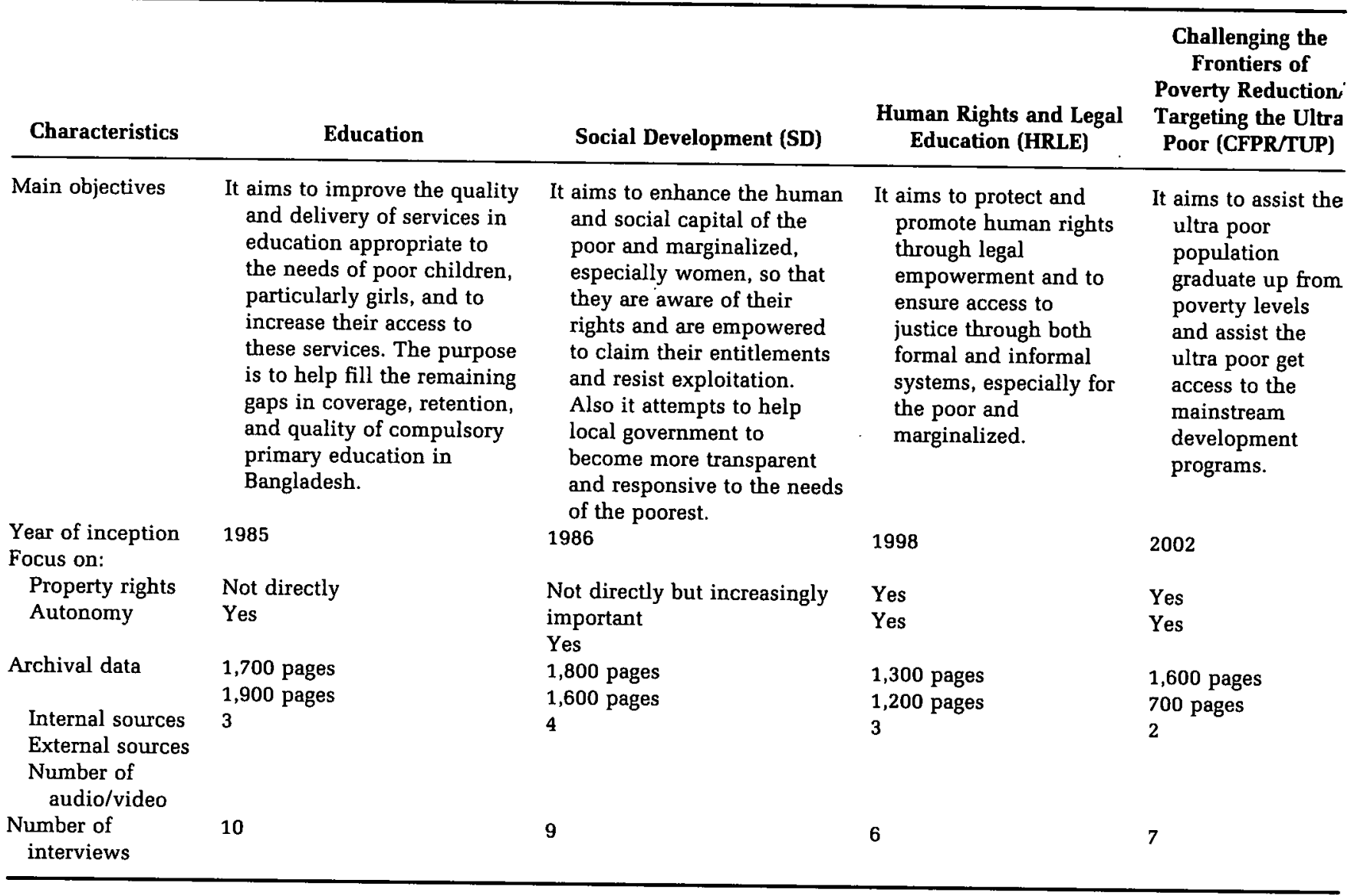

BRAC programs. Appendix A summarizes the participant observation details in full.

In addition to interviews and observation, we also collected a wide variety of documents for analysis, including secondary historical, legal, and political studies. We negotiated access to the extensive documentation generated by BRAC's research department as well as newsletters and local news articles. For each of the four focal programs in BRAC, we obtained procedural and organizational information, including descriptions of work tasks, project plans, training materials, and internal appraisal documents. These materials provided us with a specific understanding of the institutional context in which BRAC's market building initiatives are situated. We also reviewed provisions of the Bangladesh legal framework and a set of specialized legal texts (Pereira, 2002). This review proved especially important because it permitted us to illuminate the gap between the "in text" and "in reality" embodiments of the two focal market institutions. Finally, we discussed legal aspects of market participation with lawyers, BRAC staff members (some legally trained), and other NGO field staff.

\section{Data Analysis}

Data analysis was conducted in two main stages, a process that allowed us to go back and forth between the data and the emerging theoretical arguments (Miles \& Huberman, 1994; Strauss \& Corbin, 1998). Before either stage, we developed a narrative account of our findings by chronologically ordering the raw data. The narrative account included quotes from interviews, documents, annual and committee reports, and field notes. To corroborate our understanding of historical events as reflected in the emerging narrative, we checked the accounts with a set of informants that included the BRAC founder and chairman, several BRAC managers, and independent historians, legal experts, and Islamic scholars. The production of an historical narrative permitted us to better trace the history of BRAC's shift from a relief/assistance organization to a market-focused development organization.

This historical overview revealed a way to organize the data around the different BRAC programs. We used the qualitative analysis software Nvivo 9.0 to accomplish this analysis. Our primary data set in- 
cluded data from four portfolio programs. We used data collected on additional BRAC programs to complement and to corroborate these data. Our coding scheme built out a map and comparison of BRAC program features, paying particular attention to the variety of practices that the organization engaged in to intervene in market building. Our scheme also included a categorization of some institutional challenges evident from theory and data (e.g., patriarchal system and kinship, political structures, social norms, religious beliefs) that BRAC addresses in its efforts to promote women's market access.

Stage 1: Assessing the nature of the institutional voids. In our first stage of formal analysis, we identified instances of on-the-ground market building. We grouped these instances into relevant thematic categories (performing open coding). In this work, we built on the Weberian conception of society as a multi-institutional space, and specifically on the classic statement by Friedland and Alford (1991) that redescribes society not as an integrated whole, but rather as system of interlinked institutional arenas. Per this view, society comprises several distinct spheres of activity, each one built around a central institutional logic that specifies distinct meaning systems and orderings of reality, along with social practices that support each of these "social worlds." Everyday activities often take form at the intersection of these spheres, through contradictions or reinforcement between logics and practices (Friedland \& Alford, 1991; Thornton \& Ocasio, 1999). Our analysis in stage 1 suggested that three central institutional spheres in rural Bangladesh have direct relevance for market building: community, politics, and religion. This is consistent with findings from related studies that focus on the institutional constitution of society, specifically its economic activities (Campbell, 2004; Greif, 2006; Hamilton \& Biggart, 1988; Heimer, 1999; Thelen, 2004). Moving forward, again using Nvivo, our analysis identified relevant bits and pieces of institutions (Schneiberg, 2007) and assigned each of these instances to one of the three identified institutional spheres. For instance, we allocated evidence related to "early marriage," "patriarchal system," or "kinship norms of behavior" to the community sphere category.

Once these institutional assignments were complete, we reviewed the data again to refine the initial categorical assignments. Two BRAC members and two independent informants (a legal specialist and the director of an indigenous NGO in the field of education) were also asked to verify the categorization. These outside reviewers agreed on all the assignments except one, the practice of purdah. One BRAC member suggested that this prac- tice should be assigned to the community sphere because it fit there more precisely than in the religious sphere. Given the high degree of agreement among the multiple reviewers, as well as corroboration provided by the literature, we sustained our initial decision to assign purdah practices to the religious sphere.

Using our first research question as a lens (Eisenhardt, 1989), we focused our analysis next on identifying the interfaces between the three spheres and two focal market institutions. The community, political, and religious institutional spheres are analytically distinct and segregated, but in actual practice, their boundaries blur and interface. Our analytic challenge, then, was to acknowledge the distinct practices and systems of meaning that characterize each sphere while closely examining how their interfaces create possibilities for action. We intuited that conflicting and potentially contradictory accounts, demands, and solutions that occur at these interfaces imprint the institutional voids that configure possible markets.

To develop our empirical analysis regarding this supposition, we elected to focus on two specific and well-accepted institutions central to standard accounts of markets and institutions: property rights and autonomy. In specific, we wanted to discover how each the three societal spheres we identified impacted these two market institutions. Market economies are understood to rely on the creation and enforcement of property rights (De Soto, 2000; La Porta et al., 1998). Property rights exemplify a governing and stabilizing market institution (Greif, 2006; Rodrik, 2007) because they determine "the social relationships between owners and everyone else in society" (Fligstein, 2001: 33). Regarding autonomy, modern market dealings are understood to be made by-and only by-autonomous actors (McMillan, 2002). As such, autonomy is an example of what development economists and experts have called an enabling institution (Sen, 1999): it influences whether individuals are able to offer their goods and services or benefit from the offering. Moreover, both property rights and autonomy are legal and institutional outcomes of authority and power relations (Campbell \& Lindberg, 1990; Carruthers \& Ariovich, 2004; Friedland \& Alford, 1991; Nussbaum, 2000; Sen, 2009).

These two market institutions provided focal points for exploration of the institutional interfaces and market-building challenges identified in the BRAC data. In our interviews, informants repeatedly singled out autonomy as the primary focus of NGO activity in Bangladesh. Many interviewees also mentioned that property rights have gradually gained preeminence as a focus for intervention be- 
cause of the importance of property for women's self-definition (Nussbaum, 2000). To understand how the three societal spheres in Bangladesh affect property and autonomy, we developed a set of narratives, or detailed memos, to describe each of the interface possibilities. In total, 17 narratives (approximately 5-30 single-spaced pages each) were created; each narrative contained direct quotes as well as clarifying comments produced by the research team (Maitlis \& Lawrence, 2007). By way of example, one of the narratives detailed the interface between autonomy and early marriage (associated with the community sphere). We crosschecked each narrative with three informants (one internal to BRAC and two external) to validate their fidelity with lived experiences.

Stage 2: Surfacing activities in and around the voids. Our second formal stage of data analysis focused on investigating BRAC's activities in relation to the identified institutional interfaces. We focused specifically on four BRAC programs, as described above. Although it would have been possible to focus on a greater number of programs, it became evident during the initial phase of analysis that few additional ideas and issues were emerging when we looked beyond the four portfolio programs (Glaser \& Strauss, 1967). We opted for an intensive analysis of these programs.

Our second stage of analysis comprised three steps (Pratt, Rockmann, \& Kaufmann, 2006). Figure 1 provides a schematic overview of this analytic process. The first step involved the creation of provisional categories and first-order codes (Van Maanen, 1979). We used Nvivo to keep track of the emerging categories and to view similarly coded texts simultaneously, which helped to manage the large amount of data. Following the procedures suggested by Miles and Huberman (1994), our first categorical codes provided descriptive labels for the different sorts of activities that we observed at the different interfaces. The codes were largely built upon the vocabulary of the interviewees, which included, for instance, "giving voice," "raising questions," and "building ties with the elites." Once codes were named and categories developed, we returned to the data to review categorical fidelity with the data. As Pratt et al. (2006) suggested, we either corrected a category or reconceptualized it when the revisited data did not fit it well. For instance, after several iterations and discussions we agreed that our initial category "embracing religious arguments" inaccurately highlighted the use of religion by BRAC, so we changed it to "demystifying [available religious arguments]."

The second step involved axial coding (Strauss \& Corbin, 1998), wherein we compared first-order codes with one another to clarify themes and to create second-order constructs. This was an inductive, recursive process through which we identified a set of more abstract, theory-rich constructs. To illustrate, when comparing the codes referring to BRAC's facilitation of conscientization (Freire, 1970) with codes referring to building knowledge of repertoires for poor women, we noticed that BRAC's work often helped actors develop their capacity to make sense of their situational context. To capture this idea we created a second-order construct called "developing sensemaking capacity."

\section{FIGURE 1 \\ Analytical Coding Process to Induce Theoretical Dimensions}

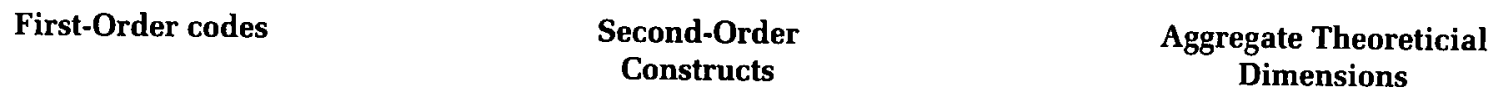

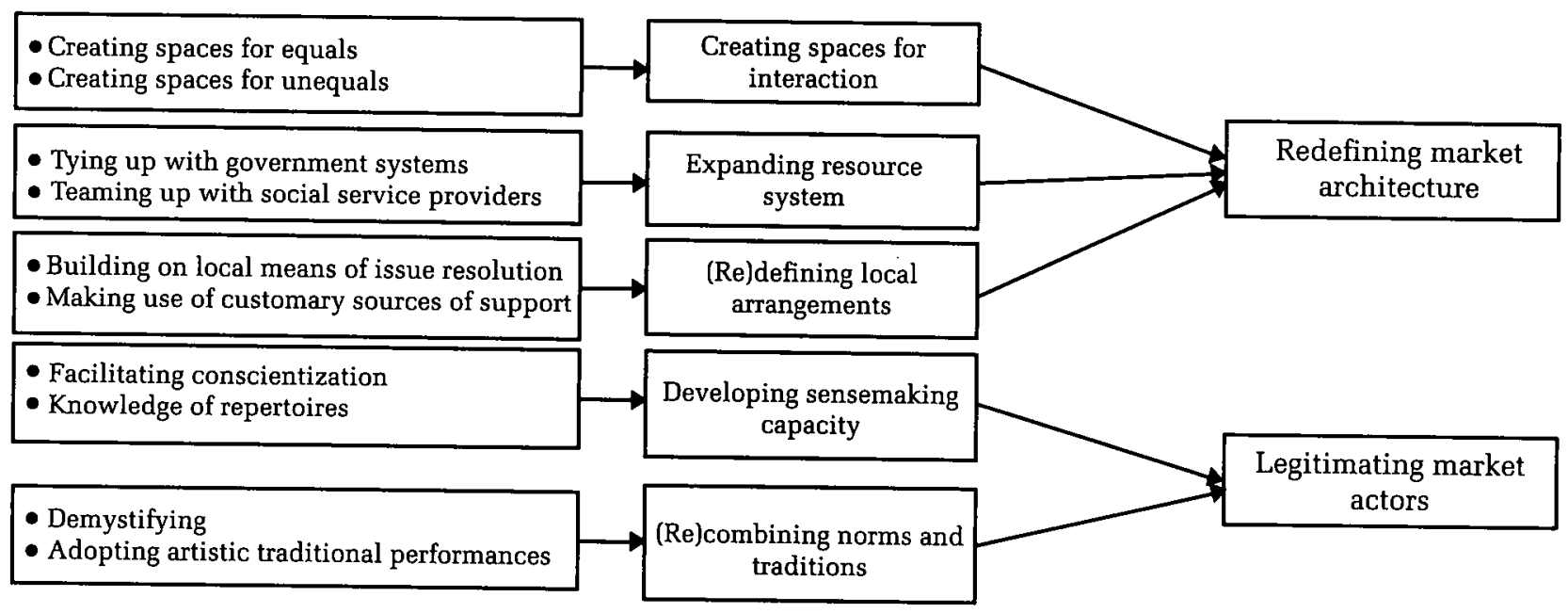


The axial coding was done by individual researchers as well as jointly by the research team. The team met numerous times to create constructs and assess the categorical fidelity of the emerging codes. These iterative discussions helped to refine the code base and to delimit the emerging theory (Creed, DeJordy, \& Lok, 2010; Pratt et al., 2006). Appendix B provides coding statistics for the key codes from each of the four portfolio programs.

Finally, in the third step we identified important dimensions from the sets of second-order constructs. For example, some categories looked structural (e.g., "creating spaces") whereas others appeared cognitive and cultural (e.g., "recombining norms and traditions"). Next, we generated alternative theoretical frameworks to make sense of how these constructs related to one another and to the literature on market building. Then we worked through the relevant insights each provided. We consolidated these available factors into two broad theoretical dimensions: "redefining market architecture" and "legitimating new actors and activities." The theoretical dimensions resonated with the data and provide further analytic guidance to understand BRAC activities to build inclusive markets. Figure 1 provides a schematic overview of this process, showing our first-order codes, second-order constructs, and derived theoretical dimensions.

\section{ANALYSIS AND FINDINGS}

Our analysis explores the resonance between the views and experiences of people on the ground in Bangladesh, the abstractions characteristic of the institutional voids literature, and the conceptual and practical work involved in market building. We present our analysis of market building in this section to illustrate the issues and to develop a provisional model of inclusive market building. Our initial findings reinforce the importance of institutional interfaces, as exemplified when three institutional spheres (community, politics, religion) shaping life in rural Bangladesh meet formal market institutions of property and autonomy.

Our analysis of property rights and autonomy relative to the institutional interfaces in rural Bangladesh points to a fresh understanding of institutional voids as the intermediate outcomes of conflicting institutional demands, norms, and reinforcing mechanisms. Voids occur at an interface because it is here that different bits and pieces of institutions (Schneiberg, 2005) collide and reconfigure spaces for social (and economic) action. Tables 2 and 3 summarize the three-way interfaces identified by our analysis and provide illustrative, direct quotations from our fieldwork. Our investi- gation of BRAC's initiatives also surfaced two key sets of market-building activities in and around institutional voids: (1) redefining market architecture and (2) legitimating new market actors. Tables 4 and 5 present data that describe these two activities in detail.

\section{Institutional Interfaces: Conflict among Institutions as a Source of Voids}

Property rights. In recent scholarship, property rights have emerged as a critical pillar of market economies (De Soto, 2000; North, 1990). The legal corpus by which Bangladesh is governed includes extensive legislation regarding property rights. According to the constitution, citizens are equal with respect to their entitlement to ownership and protection of property. Yet numerous studies have characterized Bangladesh as a country that has poor standards of property rights (Fernandez \& Kraay, 2007; Islam \& Asaduzzaman, 2008) and a judiciary system that ineffectively enforces these rights (Heritage Foundation, 2010; World Bank, 2010). Although property rights are established by law, our analysis shows that they constitute very weak pillars for markets to act as a means for poverty alleviation or a vehicle of economic and social progress. The specifics of this situation are important in illustrating the effect of institutional interfaces.

Community sphere. Poor women's market- and nonmarket-based activities in Bangladesh follow the rules of interaction established by the community. In specific, our data illustrate that institutions that relate to patriarchal and patrilineal systems, community norms, and kinship norms are in conflict with and sometimes contradict constitutional property rights. This finding offers a potential explanation for why formal property rights often go unclaimed and unenforced by many sectors of the population and therefore govern market activities and transactions weakly (see Table 2 for examples).

Social organization in Bangladesh is consistent with typical patriarchal and patrilineal rules and norms (Kabeer, 2000). The patterns of behavior.and cognition associated with this social system structure women's positions in society, impacting both public and household economies. One informant assessed the situation of property rights as one in which women have little control over resources they own:

Property rights are very unfavorable to women ... even if they have something in their name, legally, it is controlled by either husband or sons or whoever, family member ... and because of their illiteracy, backwardness, they cannot claim ownership. (interview, man, social activist) 
TABLE 2

Institutional Interfaces: Property Rights in Rural Bangladesh ${ }^{\mathrm{a}}$

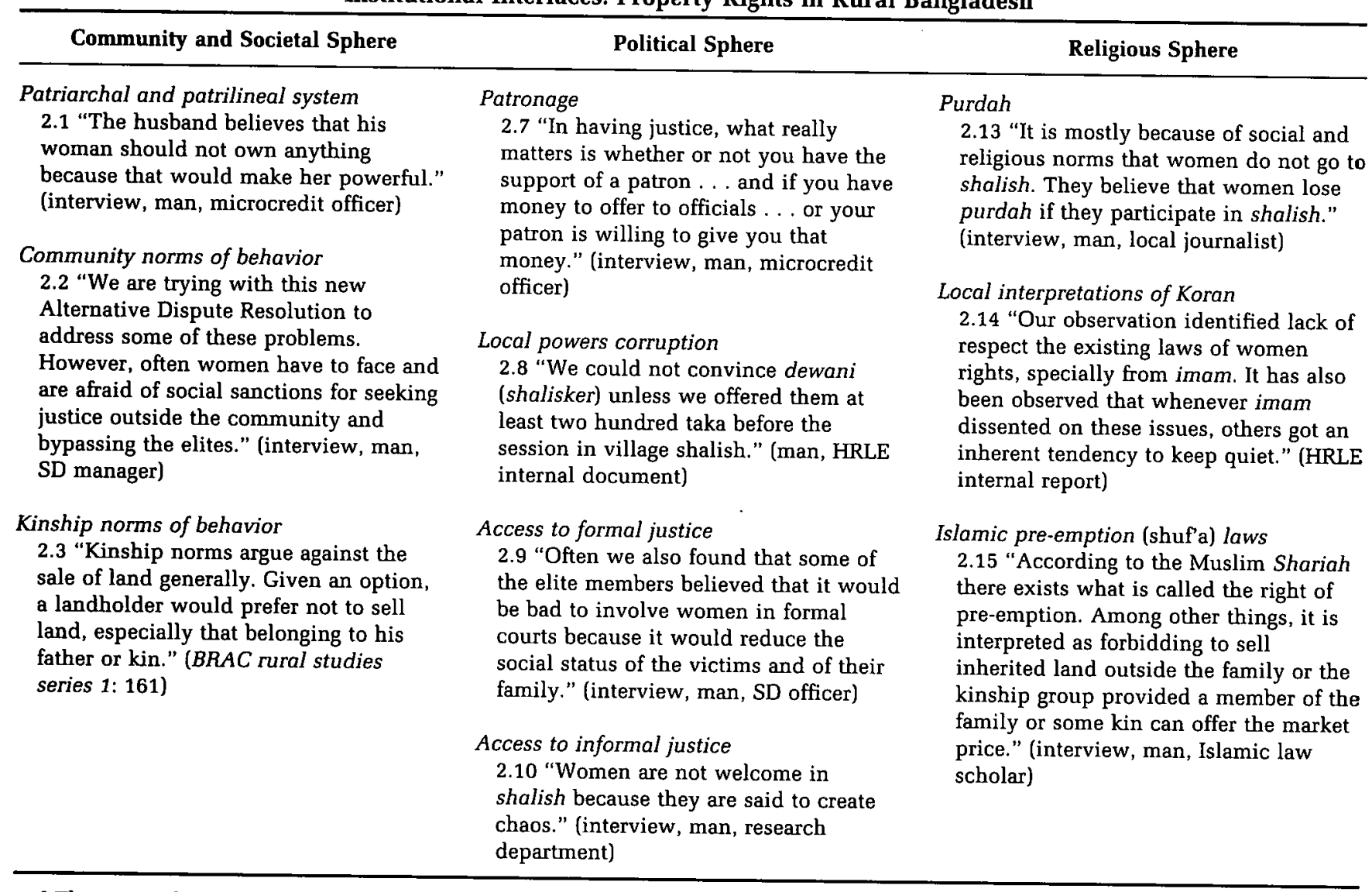

a The text and Table 1 give the spelled-out forms of abbreviations used here and in subsequent tables.

The patriarchal system in rural Bangladesh reinforces norms that confer control of women's property, income, and labor to men. Because of the risk of social sanction, women often avoid rightful claims of ownership or inheritance and do not make use of existing [formal, legal] means to convey and protect property rights. A male BRAC Social Development Program manager explained:

Wives know they must listen to and obey their husbands, and this includes the in-laws. If the woman would ask for shalish ${ }^{3}$ or other means of dispute resolution, immediately community people pass bad comments towards the woman and also the whole family, and that damages the social status within the community.

Kinship norms also constrain women's opportunities to sell and rent assets or property because they foreclose the possibility of transacting with members outside kinship groups.

${ }^{3}$ Shalish is a community-based, largely informal process through which small panels of influential local figures help resolve community members' disputes and/or impose sanctions on them.
Political sphere. Village life in Bangladesh is shaped in important ways by the decisions of local village councils. Our examination of the interaction between property rights and the local patterns of influence (i.e., patronage, corruption, and justice processes) suggest that rural Bangladesh is characterized by strong power asymmetries between different segments of the village. For example, having a patron is a key factor in favorably resolving asset and property conflicts. An informant illustrates this point:

Many poor women were exposed to a high risk that the assets they received would be stolen or damaged. Because of their lack of connections with more powerful actors ... these women cannot get the support of elites as patrons in either formal or informal-shalish-courts to enforce their own rights over their assets. (interview, woman, CFPR/TUP director)

Corruption and bribery also affect the legal and practical implementation of property rights (Transparency International of Bangladesh, 2009). Several of the people we interviewed in rural villages explained that the police were quick to accept "informal payments." Women, however, are excluded 
from participating in these practices. As one Social Development program officer, put it, "Husbands can bribe the police or lawyers to prevent going to court," but not women.

Finally, we found that the legal protection of women's property rights was further impeded by taken-for-granted beliefs and practices regarding participation in courts of informal law. As a Social Development Program coordinator explained, "We have been long trying to engage our members in traditional [informal] forms of dealing with conflicts [shalish] ... but it is very difficult since they are dominated by the male elite, which makes women's participation rather limited" (see also quotation 2.9, in Table 2).

Religious sphere. Practices and beliefs associated with religion also impact the scope and content of Bangladeshi women's social and economic activities (Kabeer, 2000). Very often these practices and beliefs are at odds with modern conceptions of property rights. Purdah is an exemplary instance of this tension. Purdah, which literally means "curtain," refers to the obligation that Muslim women have to stay close to their family relations, limit contact with unrelated men, and avoid being visible in public venues such as the village market or a court (Chen, 1983). In this way, purdah directly limits women's ability to claim or protect their property rights.

Local interpretations by rural clergy-i.e., mullahs-often promote a version of Islam that reinforces norms about virtuous women as docile and submissive. These norms create a set of social expectations that reinforce women's seclusion and foster the invisibility of women in the public sphere. These religious interpretations also constrain women's use and enforcement of property rights and conflict directly with women's constitutional rights.

When women seek to control assets and resources or participate in formal or informal courts, these claims are often interpreted as challenges to religious norms and laws. A male Social Development Program manager explained:

In disputes where some people or groups intend to appropriate some resources that have been stolen from a family or a group, there are always excuses found and in many cases fabricated, in stating that a woman from that family or group has broken the norms of Islam.

Our data reveal that the interaction between property rights and local institutional spheres is both complex and multifaceted. One of the reasons for this is that the boundaries that separate these societal spheres are highly permeable (Heimer, 1999). For example, traditional kinship norms in Bangladesh, a set of behaviors that we attributed to the community sphere, are also reinforced by Islamic pre-emption laws (shuf'a), which pertain to the religious sphere. This interaction of elements across multiple institutional spheres is particularly important to explaining the weak enforcement of property rights in Bangladesh. By way of illustration, Islamic law contains a provision for the pronouncement of fatwa (religious opinion), which many clerics and village patriarchs grossly misuse. Although the High Court made the practice of fatwa illegal in Bangladesh in 2001, religious leaders at the local level continue to exercise it widely (Pereira, 2002). An imam quoted an internal report from the Human Rights and Legal Education (HRLE) program in an interview that described the challenges of using alternative dispute resolution mechanisms when religious-legal practices are so common:

We cannot give the legitimacy of practicing such legal rights, which is controversial with Islamic laws. If we find such activities, we will protest first, and we will go against whoever goes for so.

Autonomy. As mentioned, scholars from different research traditions have emphasized the central role that autonomy plays in market building and the distributional effects of markets (McMillan, 2002; North, 1990; Sen, 2009). Bangladesh's constitution places women on an equal footing with men in all dimensions of public life. For example, Article 28(1) states that the state shall not discriminate against any citizen on grounds only of religion, race, caste, sex, or place of birth (Pereira, 2002). However, our data reveal that local community, political, and religious spheres act to limit women's autonomy and erode the ability of poor women to participate in markets.

Community sphere. Women in rural Bangladesh are socialized to be dependent. Our examination of the interaction between autonomy and the community sphere illustrates that patriarchal and patrilineal norms, as well as customs such as early marriage, stand at odds with constitutional provisions and modern conceptions of women's autonomy (see Table 3 for illustrations). The patriarchal and patrilineal system is omnipresent in Bangladesh. Women are "spoken for" first by their fathers, later by their husbands, and finally by their sons, brothers, or other male relatives. Women are also considered subordinate in most situations. When there is not enough food to feed an entire family, for example, girls are given less than their brothers. The husband of a microcredit borrower articulated, "Girls must be beaten to maintain strict control." A female manager in BRAC's Education Program explained further:

Once she is married, a girl has to sacrifice her life.

She has to give service to her husband and family 
TABLE 3

Institutional Interfaces: Autonomy in Rural Bangladesh

\begin{tabular}{|c|c|c|}
\hline Community and Societal Sphere & Political Sphere & Religious Sphere \\
\hline $\begin{array}{l}\text { Patriarchal and patrilineal system } \\
2.4 \text { "You know, what we are taught } \\
\text { is that a father always wants what } \\
\text { is best for his son and his daughter. } \\
\text { This means he can oblige his } \\
\text { daughter to get married without her } \\
\text { consent." (interview, woman, local } \\
\text { journalist) } \\
\text { Early marriage } \\
2.5 \text { "Parents give much more } \\
\text { attention to their sons' schooling } \\
\text { and education than to their } \\
\text { daughters' education. Parents feel } \\
\text { that the best they can do for their } \\
\text { daughters is to find a good groom } \\
\text { for them. Hence, they start } \\
\text { searching for brides for their } \\
\text { daughters, not for a good school." } \\
\text { (interview, woman, education } \\
\text { program manager) }\end{array}$ & $\begin{array}{l}\text { Patronage } \\
2.11 \text { "For instance, to get a position as a } \\
\text { teacher in a public school, while } \\
\text { "education" merits are important, what } \\
\text { really matters is having the support of a } \\
\text { patron." (interview, man, SD } \\
\text { coordinator) } \\
\text { Civil laws } \\
2.12 \text { "Sections } 64 \text { and } 65 \text { of the } \\
\text { Criminal Procedure Code deal with } \\
\text { the service of summons of person } \\
\text { who cannot be found. . . Here we } \\
\text { see a law that intentionally bypasses } \\
\text { women, indicating all women lack } \\
\text { agency, all being variations of some } \\
\text { form of pardianishin. In most other } \\
\text { laws the assumption is the thread } \\
\text { into the procedure, sometimes } \\
\text { managing to obscure the normative } \\
\text { assumption." (Pereira, 2002: 8-9) }\end{array}$ & $\begin{array}{l}\text { Purdah } \\
2.16 \text { "Women are under constant surveillance. } \\
\text { It is necessary to ensure that they do nothing } \\
\text { that brings sharam (shame) to their kin." } \\
\text { (interview, woman, local journalist) } \\
\text { Local interpretations of Koran } \\
2.17 \text { "Well, there exist some progressive } \\
\text { laws in recent years. However, they are } \\
\text { often ineffective because of extraneous } \\
\text { factors. One of the main such factors in the } \\
\text { case of Bangladesh is that of religious } \\
\text { political pressure. Particular religious } \\
\text { attitudes are so entrenched in Bangladeshi } \\
\text { society that they strike at the foundation of } \\
\text { progressive laws and deprive them of much } \\
\text { of their effectiveness." (interview, woman, } \\
\text { HRLE director) }\end{array}$ \\
\hline $\begin{array}{l}\text { Community norms of behavior } \\
2.6 \text { "The social stigma attached to } \\
\text { divorce is so pernicious for women } \\
\text { as opposed to men, that a woman } \\
\text { in many cases would remain with } \\
\text { her husband, even though this } \\
\text { would mean an intolerable and } \\
\text { sometimes life-threatening } \\
\text { existence. Frequently a woman has } \\
\text { no choice but to remain in an } \\
\text { unpleasant marriage because in the } \\
\text { alternative she would be destitute, } \\
\text { without any financial or social } \\
\text { means of survival." (interview, } \\
\text { woman, HRLE program, director) }\end{array}$ & & . \\
\hline
\end{tabular}

members. She is supposed to follow her husband whatever he orders to do.

Customs related to family and marriage force women to defer to men, both consciously and unconsciously, in ways that constrain their autonomy. In the case of marriage, fathers make all of the decisions. In the case of early marriage, ${ }^{4}$ which is illegal, giving a dowry ${ }^{5}$ is perceived as a moral obligation. Since the amount of dowry goes up with the age of the bride, early marriages are typically

\footnotetext{
${ }^{4}$ The legal marriage age in Bangladesh is 21 for boys and 18 for girls.

${ }^{5}$ Dowry refers to the money, goods, or estate that a woman brings to her husband in marriage. In the last few decades, the practice of dowry has become widespread, though supported neither by state law nor personal law. It is a very common source of violence against women.
}

favored. Early marriage further reduces women's autonomy by limiting their access to education. Community norms also stigmatize divorce, which heavily restricts a woman's autonomous capacity to terminate her marriage. Elements from the religious sphere reinforce marriage norms. In particular, Islamic law accords impose severe conditions on women seeking divorce by requiring them to undergo a process that is "time-consuming, expensive and in most of cases socially humiliating for the woman and her family" (Pereira, 2002: 25).

Political sphere. The public and private life of poor women in rural Bangladesh is also sharply influenced by rules and norms associated with patronage and civil laws. In the countryside, the poor secure protection from patrons by providing them services such as proxy voting in elections. In exchange, the poor receive remunerated positions or 
opportunities, such as "a position as a teacher in a public school" (quotation 2.11), access or voice in shalish processes, social security, or links to public resources such as food cards or food-for-work programs (see Matin, 2002). Well-entrenched patronclient relationships and their resulting asymmetric exchanges conflict with the quest for women's autonomy in the country. As the director of the CFPR/ TUP program explained,

It comes at the cost of dependency obligations which may endure over generations and become demeaning or arduous.

Our data also suggest that different elements of Bangladesh's legal framework, as constituted by constitutional law and general law, contradict Western conceptualizations of autonomy both in content and spirit. As we pointed out above, the constitution, especially part III ("Fundamental Rights"), embodies multiple provisions that grant rights and reinforce women's autonomy. However, our examination of institutional interfaces suggests that constitutional law may be only one of several forces in play. Several legal scholars have revealed that different pieces of legislation within the general law do contribute to hinder women's autonomy. For example,

There are several examples of what I term ultraprotective laws, impinging on fundamental rights of women with impunity, calculatedly taking on only a selective notion of women's capacity. All of these laws gravely restrict women's right to movement or choice of employment. For instance, these laws prohibit employment of women and children between the hours of $8 \mathrm{pm}$ and $6 \mathrm{a} . \mathrm{m}$. or other than between 7 a.m. and 8 p.m. (Pereira, 2002: 9)

Religious sphere. Finally, the autonomy of poor women is severely restricted by many local religious beliefs and practices. In particular, norms associated with purdah reinforce the existing gendered division of labor that is prevalent throughout society. Because women are strictly confined to the private sphere, they are prevented from becoming involved in market transactions and income generation. Even marketing products in public is prohibited for women. As one of our informants, a microcredit borrower, explained:

I cannot go to the market. My husband and my son can go... I am a woman.

Women's economic contributions are traditionally restricted to activities that can be performed on family property, such as rearing poultry or postharvest activities. Selectively, women do disobey the restrictions of purdah, yet our analysis suggests that restrictive institutional rules often prevail. One woman we met in a primary health care office confessed, "I used to work in the fields at night or when it was difficult to be seen." However, another young woman told us that her parents pressured her to stop working the fields because they were afraid that she "might fall in love with someone."

According to a female BRAC volunteer health worker, rural clergy also reinforce norms associated with the practice of purdah, solidifying the commonly held belief that "Allah made women weaker." Although this interpretation can be understood as the enforcement of a religious tenet, it is also appears as a clear cultural exemplar of men trying to consolidate their power and reinforce patriarchal structures.

Up to this point in our analysis we have looked at how the two focal institutions of property rights and autonomy are often contradict and conflict with existing beliefs and practices associated with the community, political, and religious spheres in Bangladesh. As a result of our investigation, we suggest that contexts such as Bangladesh can be seen as an area where multiple institutions exist simultaneously to shape market dynamics rather than as a locale devoid of institutions. One informant, a male social activist, articulated this thesis as follows:

Of course we have laws on property rights; of course women are, in theory, equal before the law in our constitution. The issue is not that we have few institutions, but that we have way too many! And often, well almost always, the ones that matter in our communities go against women having a more active role in society, in markets, at home, etc.

The lack of primacy regarding market institutions is due to the plurality of institutions that support local action. As evident from our informants, local practices and beliefs interact with Western conceptions of market logics; coding this interaction as simply "weakness" or "absence" of modern market institutions misspecifies the situation and underrecognizes the significance of the institutional plurality.

The results of our analysis provide evidence for a theory that institutional voids are situated, intermediate outcomes of contestation at institutional interfaces. Rather than empty spaces, institutional voids are, we suggest, dynamic spaces reconfigured by conflicting and contradictory institution flux. We emphasize the situated and intermediate features of voids as a way of better understanding why and how market exclusion occurs. This insight also serves as a starting point for both practical and policy-related efforts to build inclusive markets.

Next, we report findings from our analysis of the on-the-ground activities by BRAC as its members 
have endeavored to build inclusive markets in recent years in a context of institutional plurality and complexity.

\section{Building Inclusive Markets}

Building on data from our four identified BRAC programs, we found two broad repertoires of interventions that address the indeterminacy of the key market institutions, private property and autonomy: (1) activities that redefine market architecture and (2) activities that legitimate new actors. "Redefining market architecture" refers to the renegotiation of existing institutional arrangements to define who can access and participate in markets and under which conditions. "Legitimating activities" include building awareness and identity as well constructing social narratives that support and authorize women's roles in and access to markets.

Redefining market architecture. Within the larger category of activities that redefine market architecture, our analysis exposed three sets of activities (second-order constructs) that BRAC engages in that provide structural interventions within a complex institutional context. Table 4 maps the relevant first-order codes to direct quotations from BRAC workers, beneficiaries, experts, and policy observers that illuminate these activities. Appendix B displays descriptive statistics for the complete set of codes related to the BRAC programs in our analysis.

Create (social) spaces for interaction. The first set of activities within the frame of market architecture redefinition correspond to the construct "creating spaces for interaction." These activities consist of building platforms for interaction and dialogue. This second-order construct aggregates two first-order codes: creating "spaces of equals" and creating "spaces of unequals."

From its beginning, BRAC's social mobilization approach has been an attempt to build equal rather than hierarchical communities. The objective has been to create "free places" (Goffman, 1961) in which women feel they belong-places that contribute to the development of women's sense of self and break women's dominant relations of dependence. For instance, in referring to BRAC's village organizations (VOs), a VO member told us that "[we] had learned how to get together and help each other." VOs, which consist of 35 to 50 women from a single village, are seen by BRAC as "the key" and "the base" of their activities (quotation 3.2) because of their ability to redefine women's traditionally passive roles. Building these VO spaces requires a small, but continuous, set of interactions. According to Social Development Program organizer:
Then you have a small group in another community then you ultimately expand the small group into the village level and then you meet the VO each and every day, well formally once a week in a meeting setup. But informally, everyday day and night, morning and evening you're visiting and you are having contact with them. That is how you're becoming very close to them and part of them. That is how it begins.

These spaces for equals isolate and "de-integrate" (Touraine, 1995) women from their traditional positions and encourage them to take social action.

BRAC also builds spaces for "unequals" to reintegrate women into arenas where traditional relations, roles, and practices can be understood as elements of a negotiated and negotiable order (Strauss, 1978). The Village Poverty Reduction Committees (Gram Daridro Bimochon Committees, or GDBCs) are examples of these spaces for unequals. These include members of the local elite along with members of BRAC, VO women, and the ultra poor. These spaces are contingent, tentative, and carefully managed by BRAC because they often create conflicts at political, cognitive, and emotional levels by their very nature. BRAC facilitates consensual solutions by helping. elites to reinterpret their support for women rather than withdraw it. The CFPR/TUP program director explained further:

The language we use in motivating them [the elites], is the most important aspect ... we tell them, listen, we are a stranger here in your village, but you are the people who have been supporting them for hundreds and hundreds of years. Otherwise it would be very, very difficult to mobilize them and have them sitting with the ultra poor women.

Outreach to existing systems of services providers. The second category of activities that emerged from our analysis highlights the way that BRAC reaches out to existing service provision systems. This second-order construct aggregates the firstorder codes "tying up with government systems" and "teaming up with social service providers." As our prior analysis shows, women are often impeded from accessing many of the structures, services, and organizations that exist to support them (i.e., judiciary, education, health services). To address and modify such restricted access, BRAC has worked to "build partnerships and referral linkages with the Government" (quotation 3.12). One example of this activity is the primary education school BRAC developed when it recognized that interrupted education was a major issue impacting the develop- 


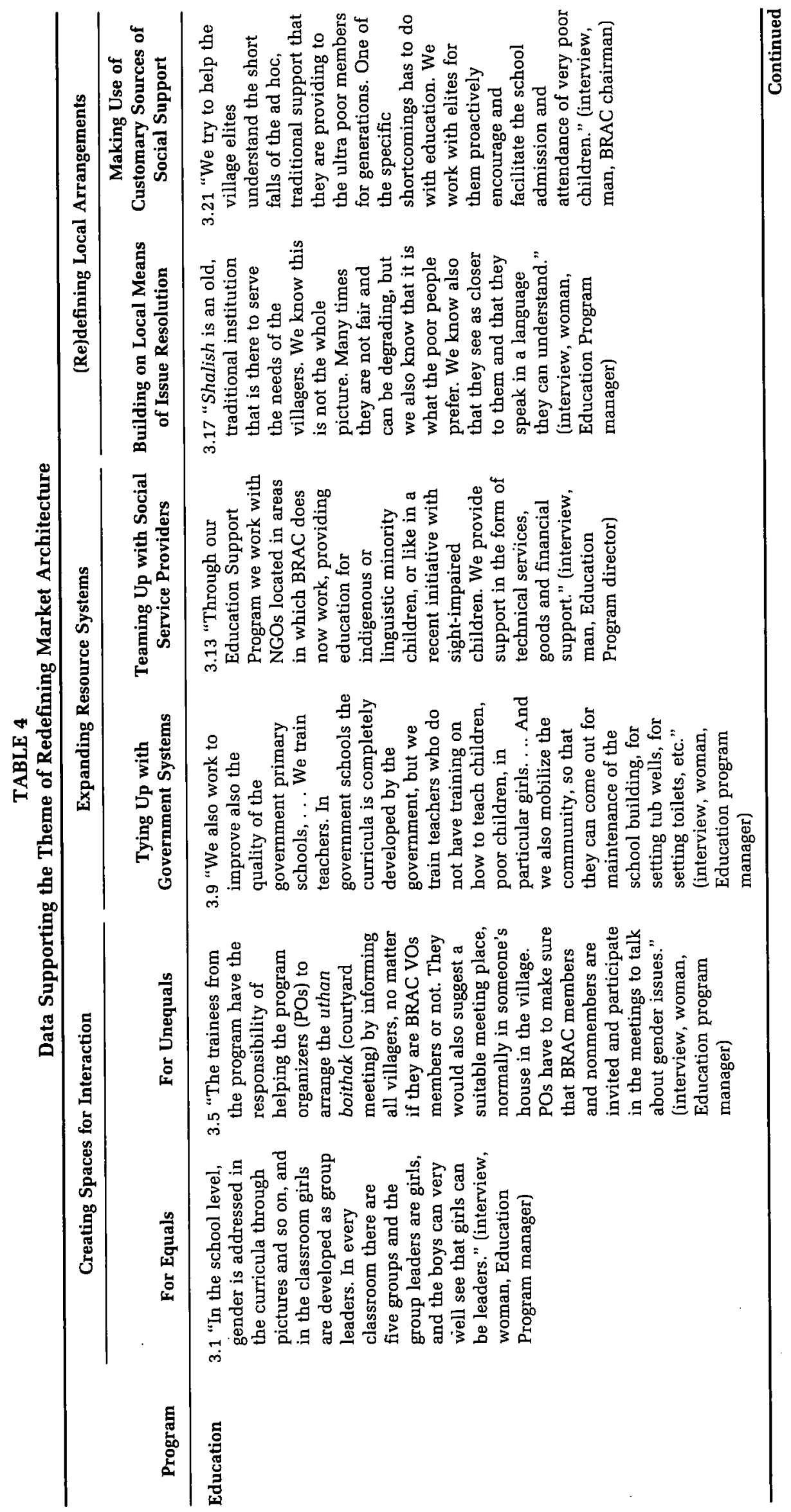




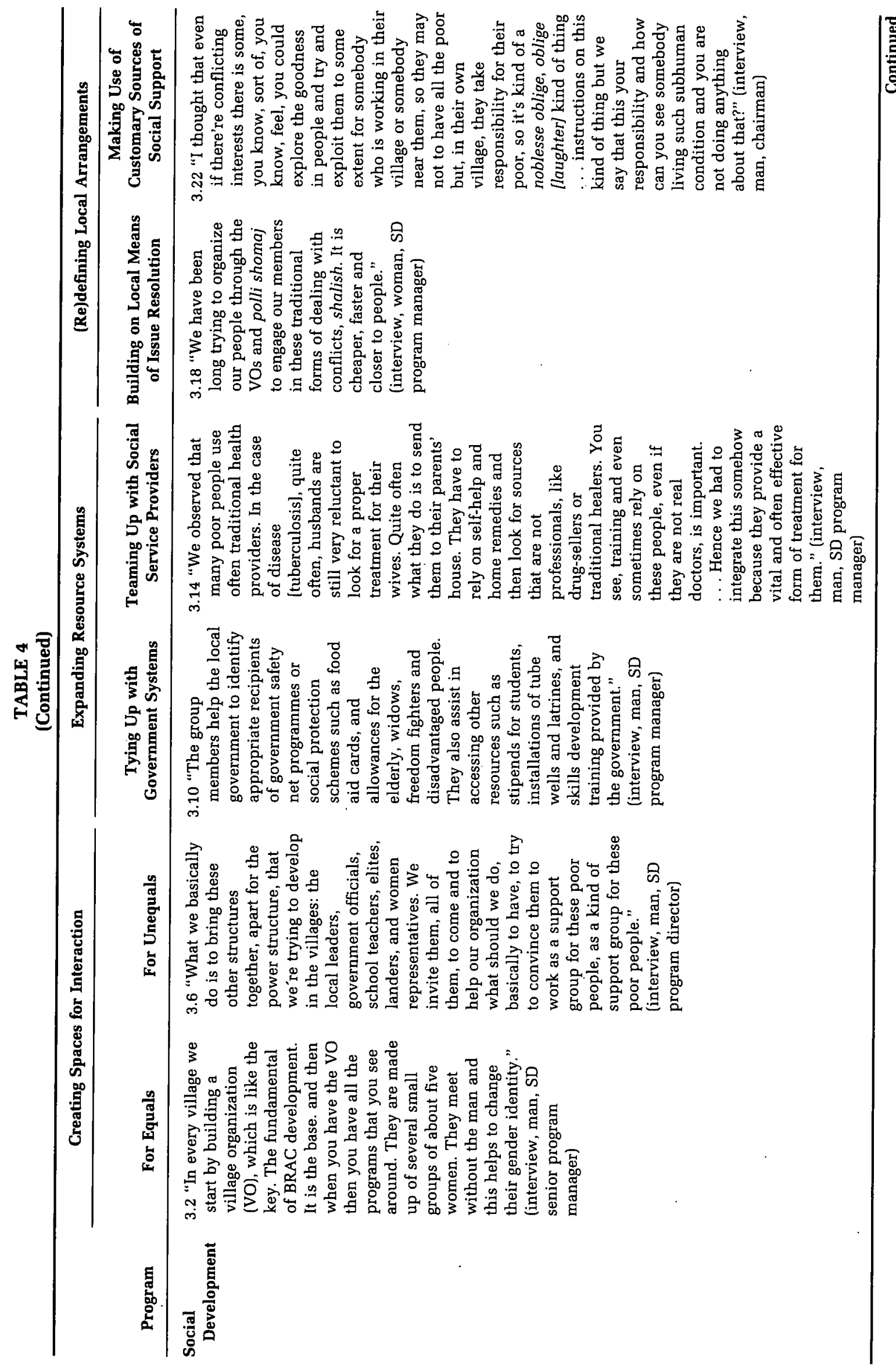




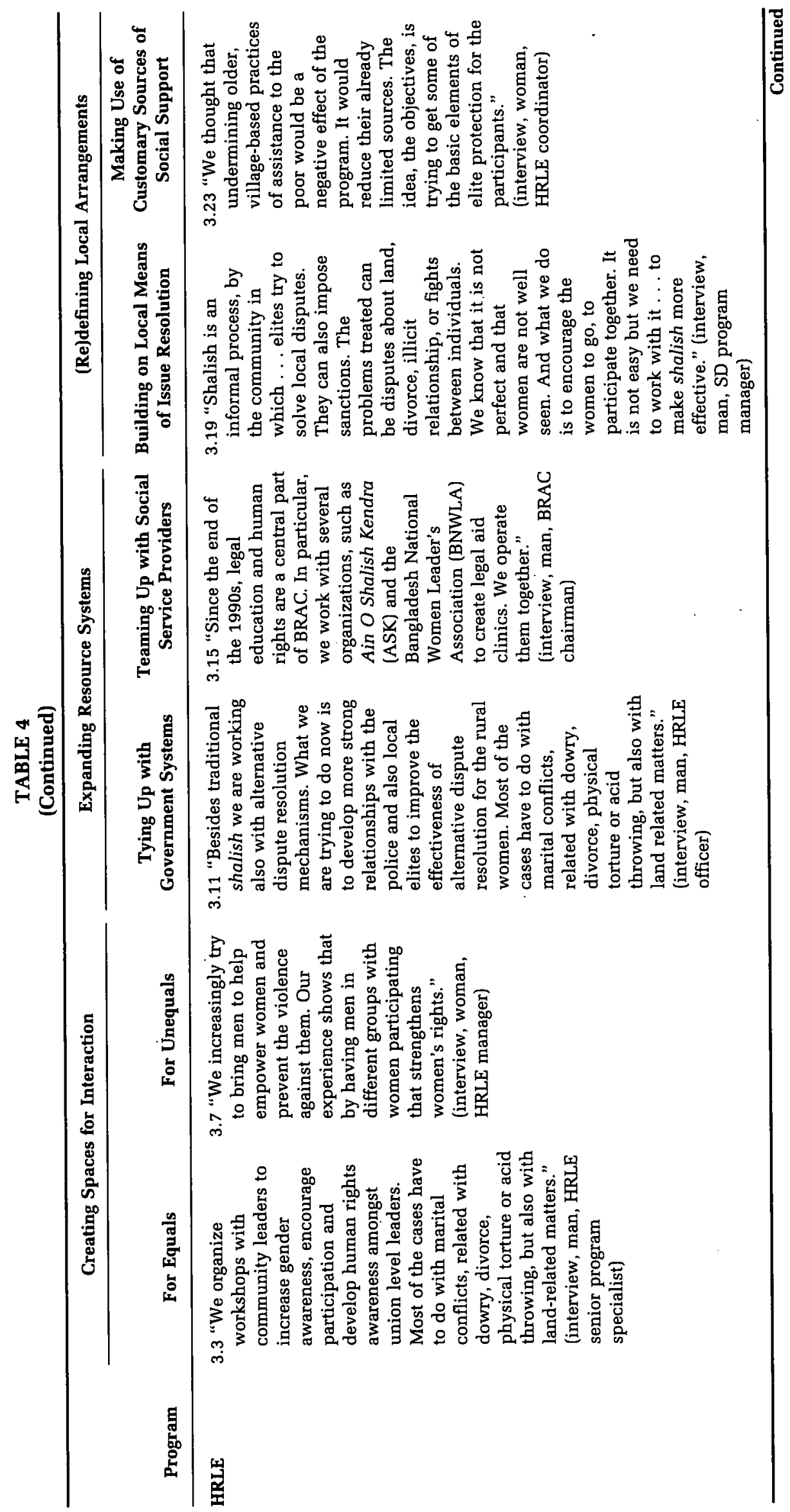




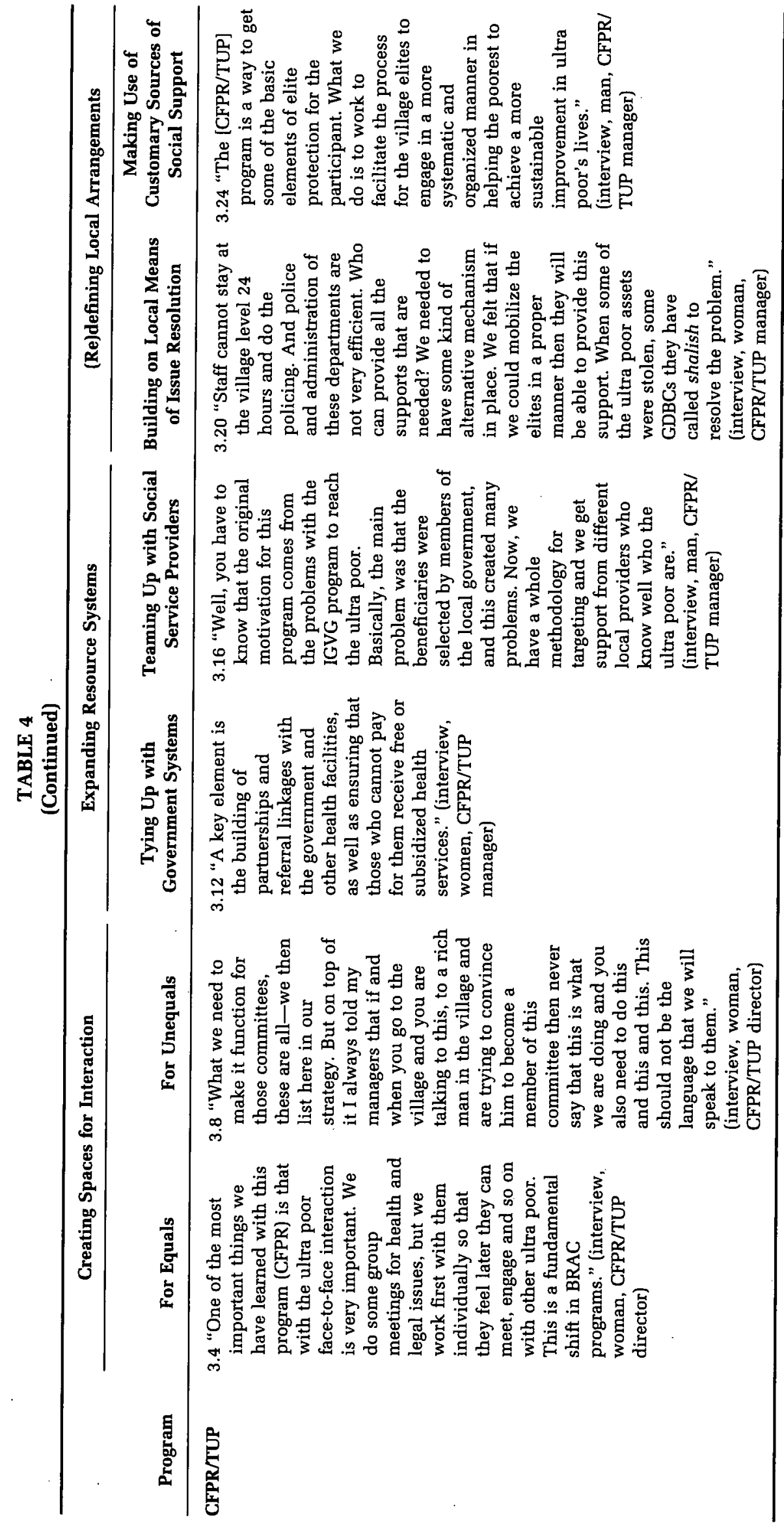


ment of girls' autonomy. A female Education Program manager told us:

Well, this was for children [70 percent of girls and 30 percent of boys] who had dropped out from the government school or who do not have access to government school. And these children are definitively poor from rural areas. They will be in school for one year, and after the conclusion of the program they will go to the government public schools, not to BRAC schools.

BRAC also teams up with service providers outside the government, such as NGOs. These alliances serve to increase women's "exit options" (Nussbaum, 2000). According to research, a woman is far more likely to stand up to abuse if she is able to read and access alternative means of issue resolution, such as legal aid clinics, employment cooperatives, and traditional healers. BRAC's partnership with Ain O Salish Kendra (ASK), a legal aid and human rights organization, exemplifies this form of outreach. An internal document from the HRLE program elaborates on the nature and objectives of such collaboration:

BRAC-ASK joint legal aid program is designed as a partnership. ASK provides orientation and training to BRAC staff . . . to familiarize them with existing laws, court procedures, and filing of cases at the police station.

Purposeful integration of BRAC initiatives with existing local support structures. The third activity we observed was the purposeful way that BRAC integrated local support structures into its various programs. The second-order construct labeled "(Re)defining local arrangements" aggregates two first-order codes: "Building on local means of issue resolution" and "making use of customary sources of social support." According to our analysis, making market access and participation for women possible seems to require learning about, making use of, and adapting to prevailing institutional arrangements-even if they are considered to be dysfunctional or if they reinforce patterns of exclusion.

Access to formal justice is tedious, costly, and frequently unavailable to women, as described above. As an alternative, BRAC attempts to engage its members in shalish, a "traditional form of dealing with conflicts" (quotation 3.18) when issues such as "land, divorce, illicit relationships, or fights between individuals" (quotation 3.19) arise. A BRAC Social Development Program manager said:

Shalish serves the needs of the villagers ... well, we know this is not the whole picture. Many times they are not fair and can be degrading, but we also know that it is what the poor people prefer. We know also that they see the members of the shalish court as closer to them and that they speak in a language they [the poor people] can understand.

In promoting the use of shalish under certain conditions, BRAC acknowledges that the needs of poor women might well be served by alternative, local sets of arrangements (Unger, 1998). Similarly, BRAC recognizes and incorporates the value of existing "older, village-based practices of assistance to the poor" (quotation 3.23) into its programs. This is a radical departure from BRAC's traditional approach to poverty alleviation, since it makes use of practices that are thought to perpetuate relationships of dependence. As the director of the CFPR/ TUP program explained:

We thought that undermining older, village-based practices of assistance to the poor would ... reduce their already rather limited sources of support. But it's good that we learned from our field and responded immediately ... we asked [the village committee] to stand up for the women in shalish processes, in ensuring the education of the children of our ultra-poor members . . to ensure . . that whatever support they are providing to the community . . . in a more organized, in an even more popular manner, will ... produce a more long-term, sustainable result.

In sum, we have identified a set of activities that redefine market architecture in ways that begin to allow poor women to engage in markets and marketbased activities. Our analysis reveals how BRAC has shifted the boundaries of spaces and activities to be more accessible and available to women. BRAC accomplishes this redefinition by extending resource and support systems and building various platforms. In so doing, BRAC brings poor women into positions that have the potential for increased discretion and autonomy at the local level.

However, development scholars and practitioners have long warned about the limits of this narrow type of liberation and empowerment (Nussbaum, 2000; Sen, 1999). Although these arrangements may temporarily ameliorate local difficulties, deeper, more taken-for-granted institutions that "identify categories of social actors and their appropriate activities or relationships" (Barley \& Tolbert, 1997: 97) can remain unchanged. Our findings highlight a second set of activities that deepen and embed marketsupporting institutional infrastructures into local institutional arrangements. This set of marketbuilding activities focuses directly on legitimating women as market actors.

Legitimating new market actors. We found that BRAC engaged in two specific types of activities 
(second-order constructs) that legitimate women's access and participation in markets. Table 5 provides quotations from our data that illustrate each of these activities along with the corresponding first-order codes. Appendix B displays statistics for the key codes used to categorize these instances within the BRAC program data.

Develop "sensemaking" capacity. The first set of legitimating activities we found, "developing sensemaking capacity," aggregates the two first-or-

TABLE 5

Data Supporting the Theme of Legitimating New Market Actors

\begin{tabular}{|c|c|c|c|c|}
\hline \multirow[b]{2}{*}{ Program } & \multicolumn{2}{|c|}{ Developing Sensemaking Capacity } & \multicolumn{2}{|c|}{ (Re)combining Norms and Traditions } \\
\hline & $\begin{array}{l}\text { Facilitating } \\
\text { Conscientization }\end{array}$ & Knowledge of Repértories & Demystifying & $\begin{array}{l}\text { Adopting Artistic } \\
\text { Traditional Performances }\end{array}$ \\
\hline Education & $\begin{array}{l}4.1 \text { "In our education } \\
\text { programs, one of our } \\
\text { main objectives is to help } \\
\text { them to collect and reflect } \\
\text { on their experiences, } \\
\text { what they know, the work } \\
\text { they do, that their parents } \\
\text { did. This is important to } \\
\text { increase their dignity. } \\
\text { And of course, creating } \\
\text { the VO is the key. They } \\
\text { have to learn that it is } \\
\text { their organization, that } \\
\text { they manage it." } \\
\text { (interview, woman, } \\
\text { Education manager) }\end{array}$ & $\begin{array}{l}4.5 \text { "These are people } \\
\text { where maybe they're not } \\
\text { able to see that they are } \\
\text { not ignorant. They can } \\
\text { think, and they can build } \\
\text { up their own, you know, } \\
\text { you can facilitate it. So, a } \\
\text { teacher, she or he is a } \\
\text { facilitator in a common } \\
\text { thinking process to } \\
\text { improve understanding } \\
\text { among people, and so we } \\
\text { still believe that it's action } \\
\text { and refraction which } \\
\text { provides the knowledge, } \\
\text { the source of knowledge } \\
\text { and not from books or } \\
\text { from other people; the } \\
\text { source of knowledge is } \\
\text { internal. You act and } \\
\text { refract and your } \\
\text { knowledge, sort of, comes } \\
\text { from a process of action } \\
\text { and refraction rather than } \\
\text { from books." (interview, } \\
\text { man, chairman) }\end{array}$ & $\begin{array}{l}4.9 \text { "With the local } \\
\text { community leaders } \\
\text { workshops what we try to } \\
\text { do is basically to } \\
\text { convince the other } \\
\text { structures, apart for the } \\
\text { power structure, that } \\
\text { we're trying to develop } \\
\text { the villages. . . We invite } \\
\text { all of them to come and } \\
\text { to help our organization: } \\
\text { what should we do, } \\
\text { basically to have, to try to } \\
\text { convince them to work as } \\
\text { a support group for these } \\
\text { poor people, as a kind of } \\
\text { support group for these } \\
\text { poor people. We also talk } \\
\text { about the laws we teach } \\
\text { and that they are not } \\
\text { contradictory to religious } \\
\text { Islamic laws." (interview, } \\
\text { man, SD manager) }\end{array}$ & $\begin{array}{l}4.13 \text { "Popular theatre also } \\
\text { attempts to engender } \\
\text { building a different } \\
\text { system of education } \\
\text { within the community- } \\
\text { nonformal education } \\
\text { accessible to all. Implying } \\
\text { that it does not rely on } \\
\text { literacy-that would at } \\
\text { once exclude the vast } \\
\text { majority of the poor. It is } \\
\text { a process centered round } \\
\text { the people, starting and } \\
\text { ending with the } \\
\text { expressive potential of } \\
\text { the human body. Thus, } \\
\text { learning over here is more } \\
\text { than entertainment, as the } \\
\text { process of learning is } \\
\text { user-friendly. Popular } \\
\text { theatre is inexpensive to } \\
\text { organize as it does not } \\
\text { require an expensive } \\
\text { outlay in equipment or } \\
\text { infrastructure." } \\
\text { (education report) }\end{array}$ \\
\hline $\begin{array}{l}\text { Social } \\
\text { Development }\end{array}$ & $\begin{array}{l}4.2 \text { "[We always] start with } \\
\text { the VO. It is the tool that } \\
\text { permits the women to } \\
\text { start thinking about their } \\
\text { problems and their lives. } \\
\text { Also to start thinking } \\
\text { about what they can do if } \\
\text { the work together. This is } \\
\text { how we have always } \\
\text { understood our work, like } \\
\text { Freire. It has to contribute } \\
\text { to raising awareness and } \\
\text { start breaking unequal } \\
\text { relationships." (interview, } \\
\text { man, SD manager) }\end{array}$ & $\begin{array}{l}\text { 4.6 "So what the women } \\
\text { members of the Palli } \\
\text { Shamajs have realized is } \\
\text { that they can include } \\
\text { themselves as members of } \\
\text { the local committees, the } \\
\text { mosque committee, } \\
\text { madrasa committee, } \\
\text { school committee. And } \\
\text { many have succeeded ... } \\
\text { so they then become more } \\
\text { powerful." (interview, } \\
\text { man, SD program officer) }\end{array}$ & $\begin{array}{l}\text { 4.10 "When POs visit } \\
\text { households, they are } \\
\text { usually offered with } \\
\text { chairs or stools to sit. } \\
\text { However, as a matter of } \\
\text { strategy, POs instead of } \\
\text { sitting on stool/chair, sit } \\
\text { on the ground. This } \\
\text { makes the people } \\
\text { embarrassed, but happy! } \\
\text { They are embarrassed } \\
\text { because they are not used } \\
\text { to seeing an educated } \\
\text { outsider sitting on the } \\
\text { ground with them. But } \\
\text { they are happy because } \\
\text { the PO sits with them in } \\
\text { an informal way as a } \\
\text { nearer one which creates a } \\
\text { fellow feeling among them } \\
\text { and the gap becomes } \\
\text { narrower." (Social } \\
\text { Development report) }\end{array}$ & $\begin{array}{l}\text { 4.14 "It comes from our } \\
\text { folk, popular culture. We } \\
\text { realized we can use it as } \\
\text { a communication tool, } \\
\text { communication network. } \\
\text { As in the early days there } \\
\text { was no electricity, no } \\
\text { radio, no television, } \\
\text { people used to do this } \\
\text { kind of drama in the rural } \\
\text { areas. So we actually } \\
\text { went back to borrow this } \\
\text { idea. People have nothing } \\
\text { else to do, so they come } \\
\text { and see the drama. People } \\
\text { love to see, and through } \\
\text { this people can become } \\
\text { educated, more aware } \\
\text { about their situation, their } \\
\text { rights, their problems, } \\
\text { issues." (interview, man, } \\
\text { SD manager) }\end{array}$ \\
\hline
\end{tabular}


TABLE 5

(Continued)

\begin{tabular}{|c|c|c|c|c|}
\hline \multirow[b]{2}{*}{ Program } & \multicolumn{2}{|c|}{ Developing Sensemaking Capacity } & \multicolumn{2}{|c|}{ (Re)combining Norms and Traditions } \\
\hline & $\begin{array}{l}\text { Facilitating } \\
\text { Conscientization }\end{array}$ & Knowledge of Repertories & Demystifying & $\begin{array}{l}\text { Adopting Artistic } \\
\text { Traditional Performances }\end{array}$ \\
\hline HRLE & $\begin{array}{l}\text { 4.3 "It is very difficult to } \\
\text { stop early marriage, so } \\
\text { now we organize } \\
\text { community workshops } \\
\text { with imams, religious } \\
\text { people, with those who } \\
\text { hold power in the } \\
\text { community. We are } \\
\text { creating awareness among } \\
\text { stakeholders, like } \\
\text { religious leaders, etc." } \\
\text { (interview, woman, HRLE } \\
\text { director) }\end{array}$ & $\begin{array}{l}4.7 \text { "In our training } \\
\text { programs one of our } \\
\text { objectives is to help them } \\
\text { to collect and reflect on } \\
\text { their experiences, what } \\
\text { they know, the work they } \\
\text { do, that their parents did. } \\
\text { This is important to } \\
\text { increase their dignity. } \\
\text { And of course, creating } \\
\text { the vO is the key. They } \\
\text { have to learn that it is } \\
\text { their organization, that } \\
\text { they manage it." } \\
\text { (interview, woman, HRLE } \\
\text { director) }\end{array}$ & $\begin{array}{l}4.11 \text { "Our objective with } \\
\text { the HRLE Program is, } \\
\text { mostly, to let the poor } \\
\text { know their own rights, } \\
\text { that they have the law } \\
\text { and human rights. And } \\
\text { also to convince them } \\
\text { that they can ask for these } \\
\text { rights, and fight for them. } \\
\text { In a way, we waint to } \\
\text { demystify the law." } \\
\text { (interview, man, Social } \\
\text { Development manager) }\end{array}$ & $\begin{array}{l}\text { 4.15 "But popular theatre } \\
\text { also has problems. We } \\
\text { believe that it is very } \\
\text { important to have actors } \\
\text { that are women. But } \\
\text { sometimes religious } \\
\text { leaders or the village } \\
\text { leaders are against it, } \\
\text { because there are women } \\
\text { acting and also because } \\
\text { they think that the topics } \\
\text { are not correct. However, } \\
\text { actors and also program } \\
\text { organizers resist that } \\
\text { opposition. They talk } \\
\text { about how important it is } \\
\text { to talk about problems } \\
\text { that the poor have, but } \\
\text { also problems of } \\
\text { sanitation, violence." } \\
\text { (interview, woman, HRLE } \\
\text { and Advocacy } \\
\text { coordinator) }\end{array}$ \\
\hline CFPR/TUP & $\begin{array}{l}\text { 4.4 "The objective is } \\
\text { awareness about gender } \\
\text { norms and relations; } \\
\text { better understanding of } \\
\text { rationality of joint } \\
\text { ownership by men and } \\
\text { women of family } \\
\text { resources and women's } \\
\text { participation in decision- } \\
\text { making in the family." } \\
\text { (interview, woman, } \\
\text { CFPR/TUP director) }\end{array}$ & $\begin{array}{l}4.8 \text { "Understanding that } \\
\text { knowing the law and } \\
\text { rights is not enough for } \\
\text { seeking redress-one has } \\
\text { to know where to go, who } \\
\text { can help, what do. To } \\
\text { help women gain basic } \\
\text { legal skills." (interview, } \\
\text { man, CFPR/TUP senior } \\
\text { program officer) }\end{array}$ & $\begin{array}{l}\text { 4.12 "To convince elites to } \\
\text { participate in the } \\
\text { committees (GBDCs), we } \\
\text { explain the tasks and } \\
\text { activities in terms that are } \\
\text { very close to common } \\
\text { understandings of the } \\
\text { traditional and religious } \\
\text { obligation they have to } \\
\text { help the poor." } \\
\text { (interview, man, CFPR } \\
\text { senior program officer) }\end{array}$ & $\begin{array}{l}\text { 4.16 "The theaters not only } \\
\text { view society as a } \\
\text { dichotomy of good and } \\
\text { bad where the latter } \\
\text { oppresses the former, but } \\
\text { by following the trend of } \\
\text { popular theater highlights } \\
\text { the cause of the } \\
\text { oppressed in the society. } \\
\text { The theatres not only } \\
\text { highlighted the } \\
\text { implication of the } \\
\text { problems, but also the } \\
\text { causes behind the } \\
\text { problems, and most } \\
\text { importantly hinted on } \\
\text { how these problems } \\
\text { could be resolved." } \\
\text { (CFPR/TUP report) }\end{array}$ \\
\hline
\end{tabular}

der codes "facilitating conscientization" and "knowledge of repertoires." "Conscientization" refers to efforts to build awareness by provoking individual and collective self-reflection (Freire, 1970). Confronted with the strong inner sense of nonentitlement that women have, BRAC starts by leading women to think about their lives. In the words of a male Social Development Program manager:

This is a . . . two stage process. First they would come to see themselves as in a bad situation, oppressed; and then would come to see themselves as citizens who had a right to a better situation.
BRAC's use of the term "conscientization" stems from the deep influence that the Brazilian educator Freire's (1970) work had on Fazle Abed. Activities that trigger conscientization aim to provoke women into seeing and questioning their condition so that they can begin "de-naturalizing" it (Douglas, 1986). Conscientization processes involve women's becoming aware of their own sense of self and visualizing the possibilities for expanding the boundaries of permissible behavior. To develop women's sensemaking in this direction, BRAC works to generate a repertoire of resources and inner capabili- 
ties for women to mobilize (Nussbaum, 2000). Martha Chen, an early BRAC staffer, wrote in a note in 1976 (published later in 1983):

These village women possess many skills. They must be made to feel these skills are valuable. Then the women must decide for themselves what they can and want to do. (Chen, 1983)

BRAC also provides tools, skills, and resources for women. These tools and resources range from basic math and accounting training to more substantial knowledge lessons about citizen rights. For instance, referring to a new initiative by the HRLE Program to empower poor women through property rights, the program director explained:

Before property rights can empower people, people must be empowered to claim their property rights. Our legal literacy courses combine legal aid with rights articulation, taking legal empowerment beyond courts and to hands-on application at the grassroots.

(Re)combine norms and traditions. Developing women's sensemaking capacity is inherently political. BRAC's efforts to build self-awareness and foster women's mobilization are not uncontroversial and often generate opposition. In response, BRAC works to provide alternative definitions to traditional notions such as "household property." This second type of legitimating work is about "(re)combining norms and traditions" and aggregates the two first-order codes, "demystifying" and "adopting artistic traditional performances." Our epigraph at the beginning of this paper, from the work of Marta Nussbaum on human capabilities, provides a direct statement of the rationale for these activities.

Efforts to change prevailing institutionalized practices, customs, and beliefs challenge many conventions and sometimes breed opposition. A very graphic example of this occurred in the 1990s, when 110 BRAC schools were set on fire by radicals who used religious arguments to claim that mixing boys and girls in class violated the values and norms of Bangladeshi society (Riaz, 2005). Opposition can be understood as an expression against dominant actors' produced meanings-meanings that articulate implicit hierarchies, reproduce their advantages, and stabilize a particular "local world" (Fligstein, 2001; Tilly, 1998).

The evidence from our informants suggests that in traditional arrangements, women are often socialized to occupy and treated as holding dependent positions. Our analysis suggests that BRAC's engagement with poor women via participation in VOs denaturalizes and demystifies the traditional relations of male-female subordination and patronage and helps women feel at ease in the company of nonfamily "strangers." As the following quote from an internal report from the Social Development Program illustrates, this demystification is purposeful:

When Program Organizers visit households, they are usually offered with chairs or stools to sit. However, as a matter of strategy, POs instead of sitting on stool/chair, sit on the ground. This makes the people embarrassed, but happy! They are embarrassed because they are not used to see an educated outsider sitting on the ground with them. But they are happy because the PO sits with them in an informal way. Then the gap between them becomes narrower.

BRAC also works with women to demystify their view of the law as opaque, out of reach, and inapplicable to themselves. In HRLE training in particular, women discuss and learn that the law is not necessarily "contradictory to Islamic religious law" (quotation 4.9).

BRAC also works with local elites-e.g., village chiefs, religious leaders, teachers, policemen-to demystify BRAC's own interventions. For example, when CFPR program organizers approach elites to provide support to women (e.g., granting fair justice in traditional shalish), they emphasize that such support is nothing more than a more formalized version of what the local elites have always been responsible for in the community. The CFPR director told us:

First of all we acknowledged their contribution to their community, so they come to see what we ask them to do as nothing extraordinary, but ... what their father did.

In addition, BRAC carefully uses religious arguments to support its own initiatives, such as framing elite support for the poor in "terms very close to common understandings of the [elites'] traditional and religious obligation." A local journalist explained:

It directly resonates with one of the Five Pillars of Islam, which states that the rich have a moral obligation to help the needy.

The issue of public framing and presentation is important when dealing with institutions such as women's autonomy and property rights. We observed that BRAC purposively draws upon and integrates traditional artistic and cultural performances in its activities. These actions facilitate sensemaking and help to legitimize discourse that favors inclusion. This integration can also be interpreted as an experiment with old rules and practices that attempts to make sense of new situations 
(Fligstein, 2001). For instance, BRAC draws on Bangladesh's rich popular folk culture by incorporating popular theater performances into its advocacy efforts and educational projects. Theater provides a medium for discussing controversial issues that all villagers understand. A Social Development manager referred to theater's ability to

ease the public discussion about issues such as domination and exploitation, land grabbing, women discrimination, village arbitration, or harassment of women.

Elaborating on the plot of a performance one of the authors attended that gathered 300 people, including local government members and a religious leader, the manager further recalled:

Someone is beating his wife, they know there is this problem in the village, because they are from there. They take story, and they represent the drama and they ask to the audience: Do you think this should be done? Should he beat his wife? And at the end of the drama they ask to the audience, what can be learned from this drama?

Thus, via the highly legitimized institution of popular theater, BRAC introduces a new image of women's autonomy into a community and provides a venue that safely fosters debate about community norms, appropriate behaviors, and the evolution of old practices. Furthermore, by employing the medium of theater, BRAC not only permits viewers to visualize this new reality and its possible implications, but also creates a reason to discuss the causes and potential responses for the situations on display.

\section{DISCUSSION AND CONCLUSION}

This paper centers on market building in institutionally complex contexts. Our analysis of the institutional context in Bangladesh and the activities of BRAC allow us to develop a grounded theory of institutional voids built on a rich empirical case in which market building is being undertaken as a tool for economic and social development. We now elaborate on how our findings contribute to and extend existing institutional accounts of the formation and functioning of markets.

\section{From Institutional Voids to Institutional Interfaces}

There may well be some instances and arenas that are "empty" of institutional arrangements; however, they are uncommon. Although the extreme nature of such instances makes them potentially useful for analysis, our study focuses not on the absence and weakness of modern market institutions but rather on their "situatedness" within a multi-institutional context-constituting what we have called an "institutionally complex context" (Greenwood, Magán, Li, \& Céspedes, 2010; Greif, 2006). The unitary view of voids makes it difficult to imagine how markets can be built or operate within anything other than a very narrow set of institutional contexts. This view also reinforces a compensatory view of institutional arrangements, rather than recognizing how indigenous institutions do support varied complex market activities and governance (Ostrom, 1990; Pierson \& Skocpol, 2002). Our research enables a move away from abstraction toward a grounded knowledge of institutional voids shaped by investigating how they take form and are managed in the process of market building. We arrived at this insight by acknowledging the existence of multiple institutional logics and analytically identifying interfaces as the points at which these logics come together. This perspective made it possible to conduct a fine-grained examination of two core institutions related to market creation and stability: property rights and autonomy.

Our data reveal that property rights and autonomy-taken for granted as pillars of markets in modern societies and economies-often contradict and thus stand in conflict with existing rules of the game in local community (e.g., patriarchy, early forced marriage), political (e.g., corruption and patronage), and religious (e.g., interpretations of religious credos, purdah) spheres in Bangladesh. These institutional interfaces configure exclusionary markets, a point we note is secondary in the literature on institutional voids and merely noted in passing by institutional economists concerned with distributional outcomes of markets. The approach introduced in this study focuses on those who are denied the chance to "play the game" and explains how many poor women in Bangladesh are excluded from market-based activities.

Attention to the interfaces between market institutions and local institutional arrangements has at least two important implications for the study of institutional voids. First, our analysis illustrates the importance of looking at a full array of interlinked institutional spheres (Friedland \& Alford, 1991). Understanding what prevents women from accessing and participating in markets permits us to see how various institutional logics shape existing rules of the game (North, 1990). Our findings that patriarchal systems, religious beliefs, and local conceptions of "proper" behavior limit women's access to and participation in markets suggests that existing institutional arrangements, and the result- 
ing institutional voids, can be seen as outcomes of cultural and political contention among actors with differential power and competing frames (Bartley, 2007; Campbell, 2004; Rao, 1998). We show that the protection of property rights is variably granted by the powerful to some but not to others. As a result, the institutional arrangements that shape institutional voids can be understood as relatively durable, but contestable, compromises based on specific coalitional dynamics that are potentially vulnerable to shifts.

Second, our focus and mapping of both market and nonmarket institutions specifies more fully the institutional arrangements relevant for understanding market-based activities in developing countries. In referring to bottom of the pyramid markets, Webb et al. pointed out that there is "little to no property rights protection available in the event of violations" (2010: 506). Our analysis suggests that alternatives such as traditional means of issue resolution have consequences for market building and access. Not only do these alternative mechanisms exist, but they are often preferred by local actors because of their cultural and cognitive proximity and ease of use. Of course, such mechanisms are not ideal; as we show, they are often captured by dominant actors and serve to reproduce existing patterns of subordination and exclusion. However, our investigation of BRAC's interventions shows that it is not always necessary to create replicas of Western institutions when they are absent or weak. Rather, adding to one of the main lessons derived from developing countries (Rodrik, 2007) and "marketization" processes in Eastern Europe (Kogut et al., 2000; Stark, 1996), we echo Dixit, who wrote "It may be possible to work with such alternative institutions as are available, and build on them" (2004: 4).

In sum, we propose that apparent institutional voids can be seen as useful problem-sensing tools. They can help to diagnose conditions that need to be addressed for inclusive market initiatives to develop. They are analytical spaces (Mahoney \& Thelen, 2010) in which elements from a variety of institutional spheres, each built around central systems of meanings and social practices (Friedland \& Alford, 1991), come together and affect the interpretation, enforcement, or embodiment of certain focal institutions-such as, in our case, property rights and autonomy (Carruthers \& Ariovich, 2004).

\section{On the Work of Building Inclusive Markets}

This article builds on existing scholarship on markets and institutions but refocuses on actors and activities on the ground. In contrast to previous work that highlights the role of the state, firms, social movements, or entrepreneurs in marketbuilding processes, we begin with a focus on a key intermediary actor, BRAC, but we also provide a more detailed analysis of a range of individual actors and communities, along with various inhabitants of existing social structures and institutional logics. We focus on market building, not simply market formation, to emphasize the activity and processes involved. And we also focus on market building that has the explicit purpose of including the formerly excluded.

Our reading of autonomy and property rights as void for many becomes the starting point for examining BRAC's efforts to build inclusive markets. Like other liminal spaces, the interfaces we examine represent spaces that illuminate the conflict that occurs over and within institutions (Mahoney \& Thelen, 2010; Morrill, 2006). These interfaces, though seemingly fixed in many ways, are also unstable and contested, and therefore represent opportunities for actors to create and transform the relations, boundaries, or rules of the game within them (Fligstein, 2001; Lawrence \& Suddaby, 2006; Santos \& Eisenhardt, 2009). Our approach reflects the centrality of such microsocial processes, interactions, and (re)negotiations for understanding how institutions "act and play" (Barley, 2008).

We find that on-the-ground market-building activities situated in institutionally complex contexts enable market access and participation through the renegotiation of existing social orders. An intermediary organization initiates this process of renegotiation, but it unfolds on behalf of and with the people affected, the marginalized (poor women) and the ones who marginalize (elites, religious leaders, etc.). It includes two distinct categories of activities: redefining market architecture and legitimating new actors.

Our findings support a perspective on market building in which markets are viewed as built along with rather than on top of existing local institutions and that allows "markets to become" rather than pushes for "markets to exist." In contrast to previous work, we integrate market consequences into our argument. This move underscores the value of attending to plural institutional spheres and provides a more complete understanding of how markets form, how intermediaries impact markets, and why it is important to take into account dimensions of inclusiveness. This perspective suggests that the inclusive market that BRAC is striving to build amalgamates with the existing local institutional arrangements rather than constituting an isolated institutional sphere. 
Our findings illustrate how market-building activities are located at the interfaces of institutional spheres and how they often modify existing norms, beliefs, and practices to alter the underlying social order (Strauss, 1982). Our study sees market access and participation as negotiable and market boundaries as potentially permeable for actors who have been excluded. These findings and interpretations reinforce ongoing conversations about inhabited institutions (Barley, 2008; Hallett, 2010; Scully \& Creed, 1999).

Our findings related to redefining market architecture extend the current view that markets can adopt different architectures. According to the sociology of markets literature, markets and their supporting institutions are built through rules, conventions, and the codification of meaning in the form of standards (Beckert, 2007; Biggart \& Beamish, 2003; Fourcade, 2007). Once a particular architectural configuration takes form, it defines who can do what and who has access to what, and it becomes difficult to stray from the configuration (Fligstein, 2001).

This stream of work emphasizes market structures, however, in ways that are sometimes overly stylized or abstract. Instead, we suggest that attention to negotiation activities surrounding existing institutional patterns can show how inclusive markets can be renegotiated even from initially restrictive structures (e.g., to formal justice). Moreover, focusing on market architecture highlights the pivotal role that different types of social spaces play relative to market building. Some purposively designed spaces may be privileged settings in which individuals from disparate groups can (re)negotiate existing social orders and seek microinstitutional change. Recent work by social movement scholars (Polleta, 1999) and organizational theorists (Kellogg, 2009; Zietsma \& Lawrence, 2010) suggests the importance of different social spaces for these ends. Our findings speak to and provide an empirical path to continue these conversations.

Our analysis also reveals how purposeful effort to legitimate new market actors complements initiatives to define and shape market architecture. Our findings echo perspectives in entrepreneurship that combine legitimacy and cognitive-based strategies and suggest that persuasion and influence can be used to overcome the skepticism and resistance of those who guard the status quo (Aldrich \& Fiol, 1994). In addition, various studies have shown how actors bestow legitimacy on practices, products, and services (Suchman, 1995; Vaara \& Tienari, 2008) by using speaking and writing (Lawrence \& Suddaby, 2006: 56), rhetoric (Green, 2004; Suddaby \& Greenwood, 2005), or analogies and metaphors (Etzion \& Ferraro, 2010; Hargadon \& Douglas, 2001).

In line with this tradition, our study illustrates how rhetorical strategies and culture can be used as a tool kit (Swidler, 1986) (e.g., popular theater performances; local means of issue resolution) and can be actively and strategically deployed by an intermediary actor to convey legitimacy. Moreover, our study allows for an in-depth look at how legitimacy is constructed and negotiated (Barley, 2008; Strauss, 1982). "As institutional analysis takes its interpretive turn, it is well worth remembering that writing, reading and rhetoric are important for negotiating legitimacy, but words break no bones" (Barley, 2008: 507). Our study represents an attempt to do so by applying a more diverse repertoire of methods (see also Dover \& Lawrence, 2010) to study institutions inhabited and at play in less than comfortable or conventional contexts (Bamberger \& Pratt, 2010).

\section{Limitations and Conclusions}

This study reports on the activities of BRAC to build inclusive markets in rural Bangladesh. We do not intend to claim that our findings represent the only way in which inclusive markets might be built. In fact, we do not believe that there is only one way to build markets (Rodrik, 2007). Our intention was to illustrate how exclusion from market activities can be traced back to institutional voids and to surface the microprocesses involved in building inclusive markets by examining the activities and role of an intermediary.

Markets are not constructed de novo (Stark, 1996). The choice of setting and the local conditions exemplified in this case restrict the generalizability and transferability of its findings, particularly with regard to modern societies in which processes of secularization have diminished the centrality of religious institutions and to societies in which what we call the emporium of the law grants inclusion effectively. However, our analytical approach of spotting possible voids and theoretical insights on the negotiated order of market access and permeability of market boundaries might provide a useful lens for researchers and decision makers studying a variety of phenomena. For example, the recent demographic shifts and the consequent rise of "Islamic banking" in Europe represent an interesting setting for analyzing how to make [financial] markets more accessible in modern societies.

Despite these boundary conditions, an extreme case in complex institutional context such as the one presented in this paper offers an opportunity to 
study a familiar set of processes and phenomena on fresh terms and to focus in on key elements that existing work has neglected (Bamberger \& Pratt, 2010). Moreover, too much research on institutions has been "embarrassingly . . . constructed by U.S. scholars based on data collected from U.S. organizations" (Scott, 2005: 478). Our case stands apart in showcasing an "unusual" (albeit, in reality, very customary and ubiquitous) and a largely unexplored setting. This case of market building in rural Bangladesh is uncommon and analytically extreme in the literature, but common in the world and hence, relevant and timely for our research community

\section{REFERENCES}

Ahlstrom, D., \& Bruton, G. D. 2006. Venture capital in emerging economies: Networks and institutional change. Entrepreneurship Theory and Practice, 30: $299-320$.

Aldrich, H. E., \& Fiol, C. M. 1994. Fools rush in? The institutional context of industry creation. Academy of Management Review, 19: 645-667.

Anteby, M. 2010. Markets, morals, and practices of trade: Jurisdictional disputes in the U.S. commerce in cadavers. Administrative Science Quarterly, 55:606638.

Bamberger, P. A., \& Pratt, M. G. 2010. Moving forward by looking back: Reclaiming unconventional research contexts and samples in organizational scholarship. Academy of Management Journal, 53: 665-671.

Banerjee, A. V., \& Duflo, E. 2011. Poor economics: $A$ radical rethinking of the way to fight global poverty. New York: Public Affairs.

Banfield, E. 1958. The moral basis of a backward society. Glencoe, IL: Free Press.

Bansal, P., \& Roth, K. 2000. Why companies go green: A model of ecological responsiveness. Academy of Management Journal, 43: 717-736.

Barley, S. 2008. Coalface institutionalism. In R. Greenwood, C. Oliver, R. Suddaby, \& K. Sahlin-Andersson (Eds.), The Sage handbook of organizational institutionalism: 490-516. Newbury Park, CA: Sage.

Barley, S. R., \& Tolbert, P. S. 1997. Institutionalization and structuration: Studying the links between action and institution. Organization Studies, 18: 93-117.

Bartley, T. 2007. Institutional emergence in an era of globalization: the rise of transnational private regulation of labor and environmental conditions. American Journal of Sociology, 113: 297-351.

Beckert, J. 2007. The great transformation of embeddedness: Karl Polanyi and the new economic soci- ology. Discussion paper, Max Planck Institute for the Study of Societies, Colonia.

Biggart N. W., \& Guillén, M. 1999. Developing difference: Social organization and the rise of the auto industries in South Korea, Taiwan, Spain, and Argentine. American Sociological Review, 64: 722-747.

Biggart, N. W., \& Beamish, T. D. 2003. The economic sociology of conventions: Habit, custom, practice and routine in market order. In K. Cook \& J. Hagan (Eds.), Annual review of sociology, vol. 29: 443464. Palo Alto, CA: Annual Reviews.

Bourdieu, P. 2005. The social structures of the economy. Cambridge, U.K.: Polity.

Bowles, S. 1998. Endogenous preferences: the cultural consequences of markets and other economic institutions. Journal of Economic Literature, 36: 75111.

BRAC. 1979. Who gets what and why: Resource allocation in a Bangladesh village (RED Rural Study Series 1). Dhaka, Bangladesh: BRAC.

BRAC. 2009. Annual report. http://www.brac.net/ oldsite/useruploads/files/brac-ar-2009.pdf. Accessed February 11, 2011.

Campbell, J. L. 2004. Institutional change and globalization. Princeton, NJ: Princeton University Press.

Campbell, J. L., \& Lindberg, L. N. 1990. Property rights and the organization of economic activity by the state. American Sociological Review, 55: 634-647.

Carruthers, B. G., \& Ariovich, L. 2004. The sociology of property rights. In K. Cook \& J. Hagan (Eds.), Annual review of sociology, vol. 30: 23-46. Palo Alto, CA: Annual Reviews.

Chakrabarty, S. 2009. The influence of national culture and institutional voids on family ownership of large firms: a country level empirical study. Journal of International Management, 15: 32-45.

Chan, H.-J. 2002. Kicking away the ladder: Development strategy in historical perspective. London: Anthem.

Chen, M. A. 1983. A quiet revolution: Women in transition in rural Bangladesh. Rochester, VT: Shenkman.

Creed, D., Dejordy, R., \& Lok, J. 2010. Being the change: resolving institutional contradiction through identity work. Academy of Management Journal, 53 $1336-1364$.

Crow, B. 2001. Markets, class and social change: Trading networks and poverty in rural South Asia. NewYork: Palgrave.

De Soto, H. 2000. The mystery of capital: Why capitalism triumphs in the West and fails everywhere else. New York: Basic Books. 
Denzin, N. 1989. The research act: $A$ theoretical introduction to sociological methods (3rd ed.). Englewood Cliffs, NJ: Prentice Hall.

Dixit, A. K. 2004. Lawlessness and economics. Princeton, NJ: Princeton University Press.

Douglas, M. 1986. How institutions think. Syracuse, NY: Syracuse University Press.

Dover, G., \& Lawrence, T. 2010. A gap year for institutional theory: Integrating institutional work and participatory action research. Journal of Management Inquiry, 19: 305-316.

Easterly, W. 2002. The elusive quest for growth. Cambridge, MA: MIT Press.

Economist. 2010. Face value: BRAC in business. http:// www.economist.com/node/15546464. Accessed February $17,2011$.

Eisenhardt, K. M. 1989. Building theories from case study research. Academy of Management Review, 14: 532-550.

Eisenhardt, K. M., \& Graebner, M. E. 2007. Theory building from cases: Opportunities and challenges. Academy of Management Journal, 50: 25-32.

Etzion, D., \& Ferraro, F. 2010. The role of analogy in the institutionalization of sustainability reporting. Organization Science, 21: 1092-1107.

Fernandez, A. M., \& Kraay, A. C. 2007. Property rights institutions, contracting institutions and growth in South Asia: Macro and micro evidence. In S. Ahmed \& E. Ghani (Eds.), South Asia: Growth and regional integration: 80-109. New Delhi: Macmillan.

Fligstein, N. 2001. The architecture of markets: an economic sociology of capitalist societies. Princeton, NJ: Princeton University Press.

Flyvbjerg, B. 2011. Case study. In N. K. Denzin \& Y. S. Lincoln (Eds.), The Sage handbook of qualitative research (4th ed.): 301-316. Thousand Oaks, CA: Sage.

Fourcade, M. 2007. Theories of markets, theories of society. American Behavioral Scientist, 50: 1015-1034.

Freire, P. 1970. Pedagogy of the oppressed. New York: Herder and Herder.

Friedland, R., \& Alford, R. R. 1991. Bringing society back in: Symbols, practices, and institutional contradictions. In W. W. Powell, \& P. DiMaggio (Eds.), The new institutionalism in organizational analysis: 232-263. Chicago: University of Chicago Press.

Geertz, C. 1978. The bazaar economy: Information and search in peasant marketing. American Economic Review, 68: 28-32.

Glaser, B., \& Strauss, Y. A. 1967. The discovery of grounded theory: Strategies for qualitative research. New York: Aldine.
Goffman, E. 1961. Asylums: essays on the social situation of mental patients and other inmates. New York: Anchor Books.

Granovetter, M., \& McGuire, P. 1998. The making of an industry: Electricity in the United States. In M. Callon (Ed.), The law of markets: 147-173. Oxford, U.K.: Blackwell.

Green, S. 2004. A rhetorical theory of diffusion. Academy of Management Review, 29: 653-699.

Greenwood, R., Magán, A., Li, S. X., \& Céspedes, J. 2010. The multiplicity of institutional logics and the heterogeneity of organizational responses. Organization Science, 21: 521-539.

Greif, A. 2006. Institutions and the path to the modern economy: Lessons from medieval trade. Cambridge, U.K.: Cambridge University Press.

Hall, P. A., \& Soskice, D. W., 2001. Varieties of capitalism: The institutional foundations of comparative advantage. Oxford/New York: Oxford University Press.

Hallett, T., \& Ventresca, M. J. 2006. Inhabited institutions: social interactions and organizational forms in Gouldner's "patterns of industrial bureaucracy." Theory and Society, 35: 213-236.

Hamilton, G. G., \& Biggart, N. W. 1988. Market, culture, and authority: A comparative analysis of management and organization in the Far East. American Journal of Sociology, 94: S52-S94.

Hargadon, A. B., \& Douglas, Y. 2001. When innovations meet institutions: Edison and the design of the electric light. Administrative Science Quarterly, 46: 476-501.

Heritage Foundation. 2010. Economic opportunity \& prosperity: 2010 Index of economic freedom. http://heritage.org/index/Country/Bangladesh. Accessed July 26.

Islam, N., \& Asaduzzaman, M. (Eds.). 2008. A ship adrift: governance and development in Bangladesh (Bangladesh Institute for Development Studies). http:// www.bids.org.bd/bids-bd/images/a_ship_adrift.pdf. Accessed March 10, 2011.

Jepperson, R. L., \& Meyer, J. W. 1991. The public order and the construction of formal organizations. In W. W. Powell \& P. J. DiMaggio (Eds.), The new institutionalism in organizational analysis: 204231. Chicago and London: University of Chicago Press.

Kabeer, N. 2000. The power to choose: Bangladeshi women and labour market decisions in London and Dhaka. London: Verso.

Kellogg, K. C. 2009. Operating room: Relational spaces and microinstitutional change in surgery. American Journal of Sociology, 115: 657-711. 
Khanna, T., \& Palepu, K. 1997. Why focused strategies may be wrong for emerging markets. Harvard Business Review, 75(4): 41-51.

Khanna, T., Palepu, K. G., \& Sinha, J. 2005. Strategies that fit emerging markets. Harvard Business Review, 83(6): 63-76.

Khanna, T., \& Rivkin, J. W. 2006. Interorganizational ties and business group boundaries: Evidence from an emerging economy. Organization Science, 17: 333-352.

Korten, D. (Ed.). 1987. Community management. West Hartford, CT: Kumarian.

Kumar, N., Stern, L., \& Anderson, J. C. 1993. Conducting interorganizational research using key informants. Academy of Management Journal, 36: 1633-1651.

La Porta, R., Lopez-de-Silanes, F., Shleifer, A., \& Vishny, R. 1998. Law and finance. Journal of Political Economy, 106: 1113-1155.

Lawrence, T. B., \& Suddaby, R. 2006. Institutions and institutional work. In S. Clegg, W. R. Nord, \& T. B. Lawrence (Eds.), Handbook of organization studies: 215-254. London: Sage.

Leff, N. 1976. Capital markets in the less developed countries: The group principal. In R. McKinnon (Ed.), Money and finance in economic growth and development: 97-122. New York: Dekker.

Lincoln, Y., \& Guba, E. 1985. Naturalistic inquiry. New York: Sage.

Lounsbury, M., Ventresca, M. J., \& Hirsch, P. 2003. Social movements, field frames, and industry emergence. Socio-Economic Review, 1: 71-104.

Lovell, C. H. 1992. Breaking the cycle of poverty: The BRAC strategy. West Hartford, CT: Kumarian.

Mahoney, J., \& Thelen, K. A. 2010. A theory of gradual institutional change. In J. Mahoney \& K. A. Thelen (Eds.), Explaining institutional change: 1-37. Cambridge, U.K.: Cambridge University Press.

Mair, J., \& Martí, I. 2009. Entrepreneurship in and around institutional voids: A case study from Bangladesh. Journal of Business Venturing, 24: 419-435.

Maitlis, S., \& Lawrence, T. 2007. Triggers and enablers of sensegiving in organizations. Academy of Management Journal, 50: 57-84.

Matin, I. 2002. Targeted development programmes for the extreme poor: Experiences from BRAC experiments. Working paper no 20, CPRC. http://www. chronicpoverty.org/uploads/publication_files/ PRCPB_WP_2.pdf. Accessed March 11, 2011.

McMillan, J. 2002. Reinventing the bazaar: A natural history of markets. New York: Norton.

Mendoza, R. U., \& Thelen, N. 2008. Innovations to make markets more inclusive for the poor. Development Policy Review, 26: 427-458.
Meyer, K. E., Estrin, S., Bhaumik, S. K., \& Peng, M. W. 2009. Institutions, resources, and entry strategies in emerging economies. Strategic Management Journal, 30: 61-80.

Miles, M., \& Huberman, A. M. 1994. Qualitative data analysis. Beverly Hills, CA: Sage.

Miller, C. C., Cardinal, L. B., \& Glick, W. H. 1997. Retrospective reports in organizational research: Reexamination of recent evidence. Academy of Management Journal, 40: 189-204.

Morrill, C. 2006. Institutional change and interstitial emergence: The growth of alternative dispute resolution in American law, 1965-1995. In W. W. Powell \& D. Jones (Eds.), How institutions change. Chicago: University of Chicago Press.

Morrison, A. D. 2004. Competition and information production in market maker models. Journal of Business Finance and Accounting, 31: 1171-1190.

Morrison, A. D., \& White, L. 2009. Level playing fields in international capital regulation. Journal of Finance, 64: 1099-1142.

North, D. C. 1990. Institutions, institutional change and economic performance. Cambridge, U.K.: Cambridge University Press.

North, D. C. 1991. Institutions. Journal of Economic Perspectives, 5: 97-112.

Nussbaum, M. 2000. Women and human development: The capabilities approach. Cambridge, U.K.: Cambridge University Press.

Ostrom, E. 1990. Governing the commons: The evolution of institutions for collective action. Cambridge, U.K.: Cambridge University Press.

Peng, M. W., Sun, S. L., Pinkham, B., \& Chen, H. 2009. The institution-based view as a third leg for a strategy tripod. Academy of Management Perspectives, 23(4): 63-81.

Pereira, F. 2002. The fractured scales: The search for a uniform personal code. Calcutta: Stree.

Pettigrew, A. M. 1990. Longitudinal field research on change: Theory and practice. Organization Science, 1: 267-292.

Pierson, P., \& Skocpol, T. 2002. Historical institutionalism in contemporary political science. In I. Katznelson \& H. Milner (Eds.), Political science: State of the discipline: 693-721. New York: Norton.

Polletta, F. 1991. "Free spaces" in collective action. The ory and Society, 28: 1-38.

Powell, W. W., \& DiMaggio, P. J. 1991. The new institutionalism in organizational analysis. Chicago: University of Chicago Press.

Pratt, M. G., Rockmann, K. W., \& Kaufmann, J. B. 2006. Constructing professional identity: The role of work 
and identity learning cycles in the customization of identity among medical residents. Academy of Management Journal, 49: 235-262.

Puffer, S. M., McCarthy, D. J., \& Boisot, M. 2009. Entrepreneurship in Russia and China: The impact of formal institutional voids. Entrepreneurship Theory and Practice, 34: 441-467.

Rao, H. 1998. Caveat emptor: The construction of nonprofit watchdog organizations. American Journal of Sociology, 103: 912-961.

Riaz, A. 2005. Traditional institutions as tools of political Islam in Bangladesh. Journal of Asian and African Studies, 40: 171-196.

Rodrik, D. 2007. One economics, many recipes. Princeton, NJ: Princeton University Press.

Sachs, J. D. 2005. The end of poverty: Economic possibilities for our time. New York: Penguin.

Sako, M. 2009. Global strategies in the legal services marketplace: Institutional impacts on value chain dynamics. Working paper, University of Oxford.

Santos, F., \& Eisenhardt, K. M. 2009. Constructing markets and shaping boundaries: Entrepreneurial power in nascent fields. Academy of Management Journal, 52: 643-671.

Schneiberg, M. 2005. Combining new institutionalisms: explaining institutional change in American property insurance. Sociological Forum, 1: 93-137.

Schneiberg, M. 2007. What's on the path? Path dependence, organizational diversity and the problem of institutional change in the US economy, 19001950. Socio-Economic Review, 5: 47-80.

Scott, W. R. 2005. Institutional theory: Contributing to a theoretical research program. In K. G. Smith \& M. A. Hitt (Eds.), Great minds in management: 460-484. Oxford, U.K.: Oxford University Press.

Scully, M., \& Creed, W. E. D. 1999. Restructured families: Issues of equality and need. Annals of the American Academy of Political and Social Science, 562: 4765.

Seelos, C., \& Mair, J. 2007. Profitable business models and market creation in the context of deep poverty: A strategic view. Academy of Management Perspectives, 21(4): 49-63.

Sen, A. 1999. Development as freedom. Oxford, U.K.: Oxford University Press.

Sen, A. 2009. The idea of justice. Cambridge, MA: Harvard University Press.

Smillie, I. 2009. Freedom from want: The remarkable success story of BRAC, the global grassroots organization that's winning the fight against poverty. Sterling, VA: Kumarian.
Spicer, A., McDermott, G. A., \& Kogut, B. 2000. Entrepreneurship and privatization in Central Europe: The tenuous balance between destruction and creation. Academy of Management Review, 25: 630649.

Spradley, J. P. 1979. The ethnographic interview. New York: Wadsworth.

Stark, D. 1996. Recombinant property in East European capitalism. American Journal of Sociology, 101: 993-1027.

Stiglitz, J. E. 1989. Markets, market failures, and development. American Economic Review, 79: 197-203.

Stiglitz, J. E. 2000. Capital market liberalization, economic growth, and instability. World Development, 28: 1075-1086.

Strauss, A. 1978. Negotiations: Varieties, contexts, processes, and social order. San Francisco: JosseyBass.

Strauss, A. 1982. Social worlds and legitimation processes. Studies in Symbolic Interactions, 4: 170-190.

Strauss, A., \& Corbin, J. 1998. Basics of qualitative research: Techniques and procedures for developing grounded theory (2nd ed.). Thousand Oaks, CA: Sage.

Suchman, M. C. 1995. Managing legitimacy: Strategic and institutional approaches. Academy of Management Journal, 20: 571-610.

Suddaby, R., \& Greenwood, R. 2005. Rhetorical strategies of legitimacy. Administrative Science Quarterly, 50: $35-67$.

Swidler, A. 1986. Culture in action: symbols and strategies. American Sociological Review, 51: 273286.

Thelen, K. 2004. How institutions evolve: The political economy of skills in Germany, Britain, the United States, and Japan. New York: Cambridge University Press.

Thornton, P., \& Ocasio, W. 1999. Institutional logics and the historical contingency of power in organizations: Executive succession in the higher education publishing industry, 1958-1990. American Journal of Sociology, 105: 801-843.

Tilly, C. 1998. Durable inequality. Berkeley: University of California Press.

Tilly, C., \& Tilly, C. 1998. Work under capitalism. Boulder, CO: Westview Press.

Touraine, A. 1995. Critique of modernity. Oxford, U.K.: Blackwell.

Transparency International of Bangladesh. 2009. Annual Report: Survey on corruption in Bangladesh. Dhaka: Uttara. 
UNDP. 2008. Annual report 2008. http://www.undp.org/ publications/annualreport2008/pdf/IAR2008_ENG low.pdf. Accessed March 10, 2011.

Unger, R. 1998. Resisting gender. Thousand Oaks, CA: Sage.

Vaara, E., \& Tienari, J. 2008. A discursive perspective on legitimation strategies in MNCs. Academy of Management Review, 33: 985-993.

Van Maanen, J. 1979. The fact of fiction in organizational ethnography. Administrative Science Quarterly, 24: $539-550$.

Webb, J., Kistruck, G. M., Ireland, R. D., \& Ketchen, D. K. 2010. The entrepreneurial process in bottomof-the-pyramid markets: The case of multinational corporation/nongovernment organization alliances. Entrepreneurship Theory and Practice, 34: 555-581.

Webb, J., Tihanyi, L., Ireland, R. D., \& Sirmon, D. G. 2009.
You say illegal, I say legitimate: Entrepreneurship in the informal economy. Academy of Management Review, 34: 492-510.

World Bank. 2010. World development report: Global economic prospects. http://siteresources.worldbank. org/INTGEP2010/Resources/FullReport-GEPSummer 2010.pdf. Accessed on January 26, 2011.

Yin, R. K. 1994. Case study research: Design and methods (3rd ed.). Thousand Oaks, CA: Sage.

Zelizer, V. A. 2005. The purchase of intimacy. Princeton, NJ: Princeton University Press.

Zelizer, V. A. 2010. Economic lives: How culture shapes the economy. Princeton, NJ: Princeton University Press.

Zietsma, C., \& Lawrence, T. B. 2010. Institutional work in the transformation of an organizational field: The interplay of boundary work and practice work. Administrative Science Quarterly, 55: 189221.

\section{APPENDIX A}

Interview and Participant Observation Data

Informant

Type of Interviewee (Number of Interviews)
Type of Participant Observation (Total Number of Observations)

\section{Internals \\ BRAC management \\ $B R A C$ university \\ BRAC programs \\ Education Program \\ Social Development \\ Program \\ HRLE Program}

\section{CFPR/TUP}

Economic Development

Health Program

Research and Evaluation Department

Social enterprises

Aarong (retail)

Dairy \& Food Project

BRAC Agriculture \&

Externals

Livestock Enterprises

Other NGOs and social activists

Microfinance institution 1

Microfinance institution 2

NGO in education field 1

NGO in education field 2

Other
Chairman (4), advisory board member (2)

Pro-vice chancellor (1)

Director (1), senior manager (1), manager (2), program organizer (2), teacher (2), students (2)

Senior manager (3), program officer (2), village organization leader (1), village organization member (2)

Director (2), manager (1), program officer (1), beneficiary (2)

Director (2), manager (2), junior manager (1), Beneficiary (2)

Senior manager (2), program officer (2), borrowers (6)

Senior manager (1), program officer (1), volunteer health worker (1)

Senior researcher (1), junior researcher (1)

Senior manager (1)

Senior manager (1)

Senior manager (1)

General manager (1), program organizer (1), branch manager (1), borrowers (2)

Chairman (1), program organizer (1)

General managers (1)

Teachers (2)

Local journalist (2), Islamic law specialist (2), missionaries (2), lawyer and member of Supreme Court of Bangladesh (1), expatriate manager (2)
Attended courses in primary school (2)

Attended popular theatre performance (1)

Attended legal education classes (1)

Attended microcredit meeting (2) Attended health meeting (1)

Visited (2)

Visited (1)

Attended microcredit meeting (2) Visited local branch office (1) Attended microcredit meeting (1)

Visited garment factories (3) 


\section{APPENDIX B}

Statistics for Key Codes from the Programs Studied ${ }^{a}$

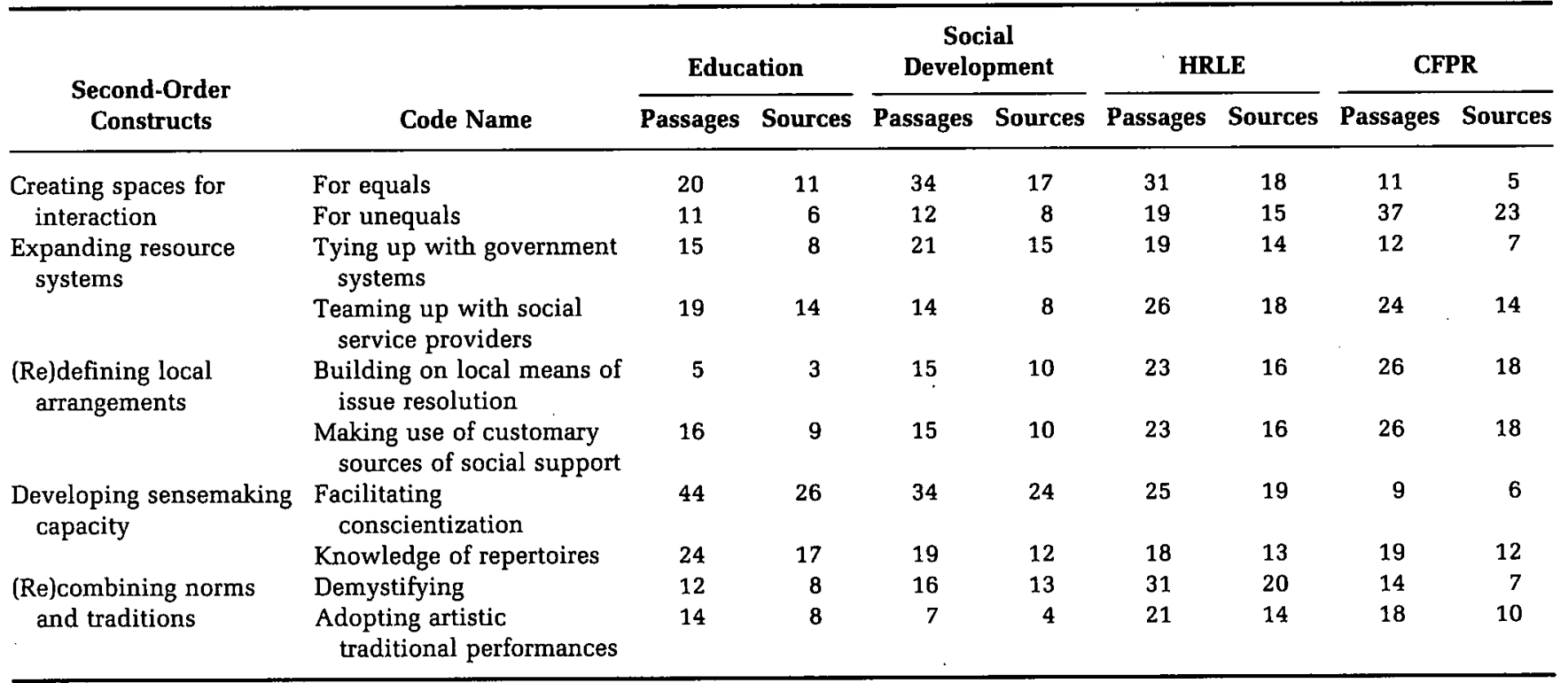

a "Passages" presents the number of passages with the code indicated. "Sources" presents the number of sources with passages having this code.

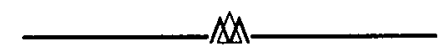

Johanna Mair (jmair@stanford.edu) is the Hewlett Foundation Visiting Scholar at the Stanford Center on Philanthropy and Civil Society and a professor of management, organization, and leadership at the Hertie School of Governance in Berlin. Her research focuses on how novel organizational and institutional arrangements generate economic and social development and the role of entrepreneurship and innovation in this process. She received her Ph.D. in strategy from INSEAD.

Ignasi Martí (marti@em-lyon.com) is an associate professor of organization theory and entrepreneurship at the EM LYON Business School, where he is member of the OCE Research Center. He received his Ph.D. from the IESE Business School at the University of Navarra. His research focuses on exclusion, dignity, resistance, entre- preneurship, power and politics, and other institutional processes.

Marc J. Ventresca (marc.ventresca@sbs.ox.ac.uk) is on the Strategy, Innovation and Marketing Faculty at the University of Oxford and is a Faculty Fellow at the Institute for Science, Innovation and Society. His research focus is the economic sociology of strategy and innovation, with empirical studies of institutionally complex contexts and market building. Current projects investigate governance innovations in knowledge-intensive organizations and industries, including global financial markets, "ancient" universities, and Amazon ecosystems services markets. He received his Ph.D. in organizational sociology from Stanford University. 
Copyright of Academy of Management Journal is the property of Academy of Management and its content may not be copied or emailed to multiple sites or posted to a listserv without the copyright holder's express written permission. However, users may print, download, or email articles for individual use. 